\title{
The application of soft systems thinking in SDG interaction studies: a comparison between SDG interactions at national and subnational levels in Colombia
}

\author{
Efraim Hernández-Orozco ${ }^{1}$ (D) - Ivonne Lobos-Alva ${ }^{1} \cdot$ Mario Cardenas-Vélez $^{1}$. \\ David Purkey ${ }^{1} \cdot$ Måns Nilsson $^{2} \cdot$ Piedad Martin $^{3}$
}

Received: 7 January 2021 / Accepted: 1 September 2021 / Published online: 28 September 2021

(C) The Author(s) 2021

\begin{abstract}
Since the approval of the Agenda 2030, researchers and policy makers have pointed out the need to understand interactions among the Sustainable Development Goals (SDGs) - suggesting that progress or the lack of progress toward one goal will affect other goals through systemic interactions, producing synergies and trade-offs. However, most of the methods used to account for these interactions rely on hard systems thinking approaches, which are limited by the absence of needed data below national levels. Moreover, a general lack of data also constrains the scope of analysis to the 17 Goals, ignoring their 169 underlying targets. Given these challenges, we report on an experiment using an example of a soft systems thinking methodology: the SDG Synergies approach, which is based not only on available information but also on the elicitation of stakeholder and expert opinions. Thus, the approach allows for analysis of target-to-target interactions at subnational scales. The study, the first of its kind, assessed interactions at two scales: the national level in Colombia and the subnational level in the department of Antioquia. The results reveal profound differences between the two scales, suggesting that national-scale analysis of SDG interlinkages is not certain to capture local-level realities. The findings raise important issues for understanding and managing cross-scale interactions. Our work suggests that soft systems thinking is more appropriate for assessing SDG interactions because such an approach lends itself to conducting target-level analysis at various scales in the face of limited data availability.
\end{abstract}

Keywords Hard systems thinking $\cdot$ Soft systems thinking $\cdot$ SDG interactions $\cdot 2030$ Agenda $\cdot$ Sustainable Development Goals (SDG)

Efraim Hernández-Orozco

efraim.hernandez@sei.org

1 Stockholm Environment Institute (SEI), Latin America Centre, Calle 71 \# 11-10, 801, Bogota, Colombia

2 Stockholm Environment Institute (SEI), Headquarters, P.O. Box 24218, 10451 Stockholm, Sweden

3 Regional Office for Latin America and the Caribbean, Clayton, City of Knowledge, United Nations Environment Programme (UNEP), Morse Ave \#103, Panama City, Panama 


\section{Introduction}

The Sustainable Development Goals (SDGs) include a set of 169 targets grouped within 17 goals adopted by the United Nations General Assembly to address the significant socioenvironmental challenges facing the world (UN, 2016). As the name suggests, the 2030 Agenda for Sustainable Development aspires to make these goals and targets a reality by 2030. Moreover, the SDGs constitute an "integrated and indivisible" strategy, within which the accomplishment of every goal and target must transpire before sustainable development truly occurs (UN, 2016). The primary challenge facing those working toward this future concerns making decisions today that properly orient development trajectories toward realizing this aspiration.

Since the approval of the 2030 Agenda, researchers and practitioners have pointed out the need to understand interactions between its goals and targets. This implies that changes in terms of one goal or target will potentially affect other goals or targets through systemic interactions-with some targets interacting negatively, producing trade-offs, and others interacting positively, creating synergies (Weitz et al., 2018). The implication is that the tenets of analysis of interconnected systems should apply to efforts to implement Agenda 2030. This interconnected approach significantly complicates policymaking, as the orientation of development trajectories over the coming decade would need to consider possible trade-offs and synergies between SDGs, and related policies and plans, to ensure policy coherence, thus respecting the Agenda's integrated and indivisible nature (Nilsson \& Weitz, 2019; Weitz et al., 2018).

In fact, many countries have begun to orient their development efforts towards the 2030 Agenda (UN, 2019). At the same time, however, scientists and international institutions are still calling for governments to strengthen their strategies to achieve policy coherence for the SDGs (Breu et al., 2020; Nilsson \& Weitz, 2019; OECD, 2019). As such, there is a need to use science-based approaches to enhance technical capacity to address possible interactions in the implementation of the Agenda (Allen et al., 2018; Sospedra \& Martin, 2005). In response, since 2015 , enough research has been published to motivate a paper reviewing the state of the art of SDG interactions-oriented literature (Bennich et al., 2020). In this review, most published articles report on the development of conceptual models of SDG interactions derived from "relevant" issued literature. However, the published research documenting specific SDG interactions and in different contexts is extremely limited (Nilsson et al., 2018). Most often, the cited literature does not specifically target the 2030 Agenda, but rather documents relationships that can be understood as synergies (e.g., access to electricity increases time spent studying) or trade-offs (e.g., increased generation of hydropower leads to the degradation of downstream aquatic ecosystems). The construction of conceptual models of specific SDG interactions, therefore, requires a mental mapping of each cited interaction onto SDGs interlinkages. This complicates standardization and, therefore, generalizability.

Other recent publications report on the application of predictive models to simulate the future co-evolution of socioeconomic indicators pegged to specific SDGs, based on the observed evolution of these indicators through time (e.g., Collste et al., 2017; Dörgo et al., 2018; Ospina-Forero et al., 2020; Pradhan et al., 2017; Spaiser et al., 2017). We identify these methods as hard systems thinking approaches, as they seek to quantify interlinkages based on quantitative models of causation within SDG interactions and derived from observed spillover effects. Proponents of these approaches argue for their replicability in that they discover potential interactions within publicly available data (e.g., Guerrero \& 
Castañeda, 2020; Ospina-Forero et al., 2020). Most commonly, however, these methods rely on time series of development indicators that are only available at the country level, which limits the scope of these studies to the national scale. Moreover, the data used typically serve as proxies for the 17 broad goals, rather than for the 169 specific targets.

The application of hard systems thinking methods implies two things. First, that aggregate patterns of national-level progress related to SDG goals reasonably represent patterns of subnational development. Second, that progress associated with an overall goal implies equivalent progress in terms of each specific target within this goal. However, many authors argue that the nature of SDG interactions will vary significantly based on local contexts and realities (Jiménez-Aceituno et al., 2020; Reed et al., 2015; Stephens et al., 2018). If true, it logically follows that subnational target-to-target interactions must be accounted for and handled to achieve policy coherence in terms of 2030 Agenda implementation (Nilsson \& Weitz, 2019; Weitz et al., 2018).

Nonetheless, most published SDG interaction studies, whether focused on literatureinformed conceptual models or indicator-informed quantitative models, do not apply to specific subnational target-to-target analyses (see Bennich et al., 2020). The proliferation of these methods has created a gap in the literature accounting for subnational target-totarget SDG interactions. Additionally, as Jiménez-Aceituno et al. (2020) noted, there are few studies comparing subnational interlinkages with national-scale interactions.

Therefore, in this paper, we report on an experiment designed to assess potential interactions between specific SDG targets as defined at the national level in Colombia and at the subnational level in the department of Antioquia. Given the challenges associated with applying hard systems thinking approaches to specific target-to-target interactions at the subnational scale, we deployed an approach we consider to be consistent with soft systems thinking: cross-impact analysis tailored for SDG analysis (Weitz et al., 2018). Henceforth, we refer to this as the "SDG Synergies approach." In contrast to hard systems thinking methods, the SDG Synergies approach characterizes interactions based on elicitation of stakeholder/expert opinion-breaking the dependence on unstandardized published literature and unavailable subnational socioeconomic indicators.

This study is the first of its kind in Colombia, and it tackles head-on the question of how the nature of SDG interactions changes when studied at national or subnational levels. This approach allowed us to explore assertions by prior researchers (Jiménez-Aceituno et al., 2020; Reed et al., 2015; Stephens et al., 2018) that the nature of SDG interactions will vary significantly based on local contexts and realities; indeed, our work with this example confirms their assertions.

Finally, having carried out the experiment, we address the question of whether our soft systems thinking approach merits deployment—even if the information required for applying a hard systems thinking approach is readily available. To tackle this question, we present some theoretical aspects of the hard vs. soft systems debate. Our understanding of this debate leads us to argue that soft systems thinking approaches to characterizing the nature of SDG interactions are preferred regardless of the scale of analysis. We present this argument in favor of soft systems thinking approaches first to better support the methodology and results of the actual experiment.

The rest of the paper is structured as follows: Sect. 2 presents a literature review. Section 3 explains the methodology. Section 4 presents and compares the findings from both experiments. Section 5 discusses the implications of the results. Section 6 concludes. 


\section{Literature review}

\subsection{A primer on soft systems thinking, and its critique of hard systems thinking}

The distinction between hard and soft systems thinking can be traced back to Peter Checkland's development of the Soft Systems Methodology (SSM) in the 1970s (Checkland \& Scholes, 1999). Checkland and other Operational Research (OR) researchers began questioning the theoretical foundation of using hard systems thinking to study social reality (e.g., Checkland, 1978; Ross \& Hoos, 1974; Shelly, 1965; Tyler, 1979; Voigt, 2011). These authors argued that, while quantitative approaches are appropriate for the study of wellstructured systems, such approaches are inadequate for analyzing systems with substantial human components (Michael C. Jackson, 1985).

This critique rested on the argument that human systems are subjective, ambiguous, and ill-structured, devoid of an objective reality endowed with universal mechanisms of causation/correlation that can be theorized and tested (M. Yolles, 1996; M. I. Yolles2020). In response, some OR researchers began to apply the interpretive/subjective social science paradigm that the social world is made up of people's distinct concepts, constructs, and intentions, and that, therefore, no universal social structures or objects can be observed independently (M. C. Jackson, 1982; Mingers, 1984; Zexian \& Xuhui, 2010). This discourse promoted Checkland to develop an alternative: the SSM. He differentiated SSM from hard systems thinking by arguing that: "None of these approaches [hard systems thinking methods] pays attention to the existence of conflicting worldviews, something which characterizes all social interactions [...] In SSM the (social) world is taken to be very complex, problematical, mysterious, characterized by clashes of worldview [...] our process of inquiry into it, can itself be organized as a learning system. [...] This shift created 'soft' as opposed to hard systems thinking" (Checkland, 1989a).

In developing this learning paradigm, where human systems are continuously constructed and shaped by the various "worldviews" (Checkland, 1989b) of the people within them, Checkland drew heavily on the prior philosophical work of Sir Geoffrey Vickers, who coined the term "appreciative systems" to refer to the systemic nature of human thinking (Vickers, 2018). According to Vickers, each person possesses a unique set of beliefs and moral standards, forming an appreciative system that shapes his or her perception of reality. Everyone has a distinct appreciative system based on the social reality that each person inhabits, perceives with his or her senses, and communicates to the rest of society. Each person's appreciative system dictates the actions in which he or she chooses to intervene. According to Vickers, this new intervened reality is again observed and interpreted, potentially changing that person's appreciative system. This cyclic process is repeated over and over, dictating how the social world is dynamically constructed. Recognizing that such a dynamic would be difficult to model from a hard systems thinking perspective, Checkland offered SSM as an alternative.

To position SSM, Checkland could not ignore that hard systems thinking models applied to human systems had been "validated" through different theoretical mechanisms (see Barlas, 1996; Oreskes, 1998). In response, Checkland and other OR researchers warned that any correspondence between the model's predictions and what is observed in reality could be explained by the existence of compulsion imposed by the structures of power and authority within human systems (Michael C. Jackson, 1985; Mike C. Jackson, 2001; Thomas \& Lockett, 1991). As Jackson (1985) says, "Because of the existence of autocratic decision-makers, the theory or model of social reality advocated by the analyst can 
be imposed upon other interests in the system - enabling those decision-makers to better predict and control the workings of the system." In other words, the appreciative systems of the actors exercising the most power, quite probably, determine the casual mechanisms that validated hard systems thinking methods seem to capture. Hard systems thinking advocates interpret these casual links as an objective social structure, which they then use to create a model. In turn, the decision-makers that exercise power can use the model to legitimize their actions, producing the outcome that the model predicts.

This is precisely what Checkland sought to avoid when he proposed SSM: "[...] we were thereafter thinking of systems models not as descriptions of something in the real world but simply as devices to organize a debate about 'change to bring about improvement'. That was the key step in finding our way to SSM." (Checkland, 1989a). For Checkland, the only validation pursued in human systems modeling emerges internally, through consensus among the actors in the system (Checkland, 1995). The core idea behind SSM is facilitating dialogue among the various actors in a system, so that people's worldviews are changed "through the eyes of another" (Banathy, 1967). In this way, decisions are reached jointly, and the structures of authority are debated and transformed (Michael C. Jackson, 1985). Echoing this argument, we believe that Checkland's work offers key insights to propose using soft systems thinking in the implementation of the 2030 Agenda. Moreover, the discussion proposed by Checkland provides theoretical grounds to confront the inclination in some policy circles to apply hard systems thinking in the implementation of the 2030 Agenda.

\subsection{Implications for the implementation of the interconnected 2030 Agenda}

We argue that the Agenda itself rests upon a set of three postulates. First, the world, defined by its current systems of power, authority, and bureaucracy, is not on a path towards sustainable development, hence the need for the Agenda. Second, sustainable development cannot be achieved by making progress in one area while conditions fail to improve or deteriorate in another, hence the assertion that the Agenda is "integrated and indivisible." Finally, existing inequities and power imbalances cannot be part of a sustainable future, hence the pledge to "leave no one behind" in implementing the Agenda.

If these postulates are true, they echo SSM's "change to bring about improvement" foundations, calling into question any effort to apply hard systems thinking to issues of interactions within the Agenda itself. Any insights revealed through the application of hard systems thinking approaches likely reflect the mechanisms of power, authority, and bureaucracy in a given country-not objective, context-independent truths of how the SDGs have interacted in the past, or should interact in the future. This distinction is essential because, if we confuse the results of hard approaches with an objective social reality about the Agenda, we miss opportunities to change the way these interactions unfold, and, therefore, to achieve integrated and indivisible progress. These changes will be derived from the recognition that the worldviews of those currently in power and those currently vulnerable can be debated and perhaps changed-modifying each actor's appreciative system, and, thus, intervening in the workings of the system itself. We believe that at the most basic level, the world defined by the 2030 Agenda will be learned, not constructed, consistent with the learning paradigm promoted by Checkland as part of SSM.

Having argued for the use of soft systems thinking approaches to understanding SDG interactions, we next explore how prominent these are within the literature emerging on the subject. In the next section, we present an overview of the use of soft systems thinking 
methodologies vis à vis other more prominent approaches, based on Bennich et al.'s (2020) state-of-the-art review of SDG interactions methodologies.

\subsection{Soft systems thinking approaches within state-of-the-art SDG interactions analysis}

The review by Bennich et al. (2020) includes a breakdown of 70 different papers on SDG interactions. Two of the criteria they used to categorize papers seem particularly relevant to our experiment in Colombia: (i) the geographical scale of the analysis; and (ii) the data sources they employ. Of the 70 papers in the review, 28 studied potential SDG interactions at scales below the global, with just three of these 28 papers examining interactions in subnational contexts (Hutton et al., 2018; Liu, 2017; Pfaff et al., 2018). Two recent, additional papers have also analyzed SDG interactions at a subnational scale (Jiménez-Aceituno et al., 2020; Wang et al., 2020). Over $70 \%$ of the SDG interaction studies rely on scientific literature (including gray literature, i.e., policy reports and news articles) and/or official databases as their input, with published literature being the most common data source. Fewer papers used expert/stakeholder knowledge or direct observations in policy processes as the primary data source.

More common are papers that use descriptions of social and natural phenomena mapped to processes related to the SDGs. Some authors (e.g., Bowen et al., 2017; Stafford-Smith et al., 2017) cite the results of scientific publications to suggest national and global cobenefits and trade-offs among various topics addressed by the SDGs, without specifying which particular SDGs interact. Other authors are more explicit about the interactions they observe, using literature to postulate connections among the SDGs, and applying conceptual modeling techniques to show how the interactions at global and national scales may unfold (e.g., Alcamo, 2019; Costanza et al., 2016; Kanter et al., 2016; Kopainsky et al., 2018; Le Blanc, 2015; Lim et al., 2018). The scarcity of relevant published papers might explain the lack of analysis on subnational SDG interactions. In this regard, we identified only two subnational interaction studies that use literature as the main data source (Jiménez-Aceituno et al., 2020; Liu, 2017).

Other papers use quantitative methodologies, informed by publicly available databases of socioeconomic indicators compiled over time at global and national scales, to argue for more scalable alternatives (e.g., Guerrero \& Castañeda, 2020; Ospina-Forero et al., 2020). These approaches calculate correlations and/or theories of causation to determine how progress toward a specific SDG potentially affects others. These represent hard systems thinking approaches. Some of these techniques include conventional statistical methods (Dörgo et al., 2018; Pradhan et al., 2017; Zhou \& Moinuddin, 2017). Others employ system modeling methodologies, such as system dynamics (Kopainsky et al., 2018; Pedercini et al., 2018), agent-based models (Guerrero \& Castañeda, 2020; Guijun et al., 2017), integrated assessment models (Bijl et al., 2017; Hutton et al., 2018; Iyer et al., 2018; Moyer \& Bohl, 2019), and econometric models (Campagnolo et al., 2018; Scherer et al., 2018). One of the most-cited SDG interactions papers is Pradhan et al. (2017), which uses the Spearman's rank correlation to find negative and positive interactions among indicators that monitor progress among the SDGs. Nonetheless, the paper uses data from the Inter-agency and Expert Group on SDG Indicators (IAEG-SDGs) (Inter-Agency \& Expert Group on Sustainable Development Goal Indicators, 2016), which are assessed at the country level. Therefore, the calculated interactions are limited to global and country scales. Most papers in this category have the same limitation. 
We have, however, identified two other approaches that can be categorized as hard systems thinking methods and that have been used in subnational studies (Hutton et al., 2018; Pfaff et al., 2018). These studies incorporate spatial analysis and socio-environmental modeling to infer interactions in localized, subnational regions. While these approaches do not use country-level development indicators, the methods employed require rigorous and high-definition spatial and environmental data, which might be scarce or unavailable — especially in developing countries (Scott \& Rajabifard, 2017). This limitation entails restrictions on the number and type of SDG interactions that can be identified, which correspond to the nature and availability of the data used the methodologies. In this regard, none of these studies cover more than 10 SDGs, and the analysis remains at the SDG (rather than target) level.

In connection to this, a potential limitation of all of these approaches is that they only allow for the evaluation of SDG-to-SDG interactions. We identified only three papers that use exclusively official databases to calculate target-to-target interactions (Bali Swain \& Ranganathan, 2021; Lusseau \& Mancini, 2019; Scherer et al., 2018). Additionally, the review of Bennich et al. (2020) cites another study that accounts for interactions among targets using datasets, but it applies a multi-criteria analysis in combination with policy analysis and stakeholder consultation (Allen et al., 2019). The lack of target-to-target interaction studies that use official datasets may be explained by the fact that the databases used lack SDG-specific information; thus the authors typically assign proxies for the 2030 Agenda (e.g., Collste et al., 2017; Iyer et al., 2018; Obersteiner et al., 2016; Rosenthal et al., 2018). However, other studies employ the information available in the United Nations Global SDG Database, alone or in combination with other datasets (e.g., Dörgo et al., 2018; OspinaForero et al., 2020; Pradhan et al., 2017). Nonetheless, many of these SDG indicators have not been conceptualized, or they are not regularly produced by countries (UN, 2020). Thus, the number of targets than can be mapped are limited, and, therefore, the data are commonly aggregated in broader Goals. For example, a study by Ospina-Forero et al. (2020) uses a multi-techniques approach that combines statistical methods with physics-inspired methods to estimate networks of SDG interactions in four countries. The authors use the Global SDG Database, which they complement with two other datasets from the World Bank and the World Economic Forum; nonetheless, their research remains limited to finding interactions among Goals due to a lack of target-related indicators. This is an important limitation that policy makers must be aware of when using SDG-to-SDG studies to design policy priorities for the Agenda. Such studies obscure the socio-environmental processes that happen at the target level, where some targets can be more catalytic than others (e.g., Järnberg et al., 2021; Lusseau \& Mancini, 2019; Weitz et al., 2018).

The lack of methodologies that can be used to understand and manage target-to-target interactions at the subnational scale has created a gap in the SDG interactions literature; most studies simply do not account for these types of interlinkages. In this regard, according to our revision, the only papers cited by Bennich et al. (2020) that could plausibly occupy this critical niche are based on "expert and stakeholder knowledge" approaches. Studies that rely on this type of input use methods that extract the subjective knowledge of relevant actors to characterize the systemic interactions of the SDGs. These represent the soft systems thinking approaches. Contrary to hard systems thinking approaches, these are not constrained by the existence of published knowledge or official databases-provided that there are relevant actors that are willing to partake in the study.

In this sense, the SDG Synergies approach (Weitz et al., 2018) deployed under this study is an example of a soft systems thinking methodology. The use of this methodology allows us to look at interlinkages at the national scale (the national government of Colombia) as 
well as the regional level (Department of Antioquia). Additionally, it is worth mentioning that, as Jiménez-Aceituno et al. (2020) noted, there are few studies comparing subnational interlinkages with national-scale interactions. Thus, to the best of our knowledge, our study is the first.

The proponents of hard systems thinking approaches raise concerns about the legitimacy of soft systems thinking approaches as applied to SDG interactions. For instance, OspinaForero et al. (2020) appeal to the use of already validated methods to compute SDG interactions and argue that none of the "first generation" SDG interaction methods (into which they group the SDG Synergies approach) "have passed any formal validation test." Here we would echo Checkland; the only validation pursued in human systems modeling emerges internally, through consensus among the actors in the system (Checkland, 1995). The SDGs were specifically designed to be "integrated and indivisible," and to "leave no one behind." Thus, we prefer to avoid methods that can only be "validated" within existing systems of power, authority, and bureaucracy, and those that have a limited scope, stemming from a view that relies solely on SDG-to-SDG interactions at the national scale. Furthermore, we are convinced that efforts to implement Agenda 2030 in local contexts can have national and/or global impacts, generating cross-scale interactions (see Hoff, 2018; Liu, 2017). Indeed, the reverse can also be true; national and global efforts can affect the local context too. Only by exploring these cross-scale interactions can we study and design bottom-up actions to enhance the global achievement of the Agenda. At least for now, soft systems thinking approaches are the only way to seize this opportunity.

\section{Methodology}

The SDG Synergies approach is central to our exploration of potential differences in SDG interactions at national and subnational scales. Thus, we first present the theoretical basis of the approach, and we then describe the workshops organized to facilitate its application.

\subsection{The SDG synergies approach}

The SDG Synergies approach (Weitz et al., 2018) is a cross-impact methodology tailored explicitly to characterize interactions among the SDGs and their targets, and to then model the network-wide implications of these characterizations. The methodology uses expertand stakeholder-based knowledge as the input, and then integrates network analysis to account for the systemic properties of the SDGs - such as synergies and trade-offs. The results can be used as a basis for policy prioritization and cooperation among sectors in charge of the implementation of specific SDGs (Nilsson \& Weitz, 2019; Weitz et al., 2018).

The approach draws from previous work on the conceptualization of SDG interactions (Nilsson et al., 2016) that proposed capturing the value of interlinkages through a sevenpoint scale: "indivisible" (+3), "reinforcing" (+2), "enabling" $(+1)$ scores to, characterize synergies; "constraining" (-1), "counteracting" (-2), and "cancelling" ( -3$)$ to characterize trade-offs; and (0) to score "consistent" values in the case of situations in which no interactions occur. In the approach, this typology is used to answer the question, "If progress is made on target $x$, how does this influence progress on target $y$ ?". The resulting scores are then introduced in a cross-impact matrix-with the influencing targets in the row elements, and the column elements indicating the influenced targets. 
The net influence of each target is determined by the sum of its interactions using the seven-point typology. The effect that one target has on every other is called the weighted out-degree, or out-degree. The degree through which one target is influenced by the rest of the Agenda is its weighted in-degree, or in-degree. A high out-degree value means that a target can make the achievement of other SDGs easier; a negative or low out-degree number indicates that the target hinders the achievement of others. A high weighted in-degree means that succeeding in the whole Agenda influences positively that target; conversely, a negative or low value for an in-degree indicates that progress in the rest of the SDGs could make progress in that target difficult.

The filled matrix is then interpreted as a weighted directed network, where each SDG target is a node, and the interlinkages between them are edges. Using network analysis allows the calculation of the second-order weighted out-degree (henceforth referred to as second-order degree), which estimates the systemic impact of one target beyond its closest neighbors.

Finally, the method also permits the detection of groups of highly connected targets through a clusterization process. In this regard, identifying clusters can guide cooperation between sectors that positively influence each other, build partnerships for governance, and set the stage for negotiations between sectors with potentially negative interactions. For this calculation we used the Gephi software and its embedded clusterization algorithm for both exercises (see Blondel et al., 2008).

\subsection{SDG targets selection for the studies}

Within the framework of the project, towards coherent implementation of the environmental dimension of the SDGs, the Stockholm Environment Institute (SEI), and the UN Environment Programme (UNEP) conducted two studies in Colombia: a national analysis, and a regional study in the Department of Antioquia. The rationale behind both projects was not only to assess SDG interactions but to directly play a role in the policy processes behind SDG implementation, creating spaces of discussion for stakeholders at both levels of government. At the national scale, we conducted a workshop oriented toward supporting Colombia's National Commission on SDGs regarding inter-institutional coordination efforts for the implementation of the Agenda. At the departmental level, we conducted a study that sought to inform the new Development Plan for Antioquia.

It has been stressed that SDG interactions are context specific. In this regard, there needs to be a contextualization phase for the SDG Synergies approach in which relevant targets are selected and mapped to their corresponding national and regional policies. Regarding target selection, the approach could potentially be used to assess interactions among all the 169 SDG targets. However, this would be time and resource intensive. Therefore, a target selection is necessary to make the method feasible. In our case studies, selection was based on three specific criteria: (1) alignment with relevant policies and plans; (2) respect for the integrated character of Agenda 2030 (addressed by including environmental, social, and economic targets, with a special focus on targets related to natural resources and their use); and the feasibility of the analysis for the time available in 2-day workshops. The target selection was made in collaboration with relevant policy makers and stakeholders behind the implementation of the Agenda at both scales. These participants also engaged in the scoring of the matrices. This means that the selected SDGs already express the motivations and priorities of decision-makers in charge of the Agenda. This is an important aspect in the contextualization phase of the methodology, which helps to focus the analysis on the 
SDGs that are perceived as most impactful, negatively or positively. Twenty targets were prioritized for the national study with the input of the National Planning Department and the Ministry of Environment and Sustainable Development. For the Antioquia exercise, 15 targets were chosen together with the national and regional partners (the full list of targets for each workshop can be reviewed on Appendix 2). From this selection, 13 SDGs appear in both studies.

The selected targets were then mapped to the relevant national and regional policies. This crucial step helps to characterize the policy processes behind the SDGs in their particular environmental, political, and economic settings. In this regard, during the workshops, the participants were provided with leaflets with the texts of the selected targets and their alignment with commitments in the National Development Plan (for the national study) or the Antioquia Departmental Development Strategy (for the subnational analysis).

\subsection{The national and regional workshops}

Two 2-day workshops were held-on November 29-30, 2018, in Medellin, for the Antioquia study; and on March 7-8, 2019, in Bogota for the national study. There were 100 participants in the national workshop, and 60 in the regional one. Some participants were selected from governmental, civil, and private institutions involved in the implementation of the Agenda at the regional and national levels; other respondents were selected based on their expertise in the topics covered. The selection process was undertaken with the national and regional partners, who considered relevant actors and potential participants to select them according to these criteria (see Appendix 1 for details about the participating institutions in the studies). For both workshops, the analysis was complemented with the web-based SDG Synergies tool (SEI, 2020), which was developed by SEI to support the application of the methodology, and to allow for quick scoring and visualizations of the results.

In the spirit of soft systems thinking, discussion groups of five or six participants were created. Organizers encouraged participants to debate the subjects up for discussion before answering questions. At the same time, each participant had personal access to the tool, meaning that he or she could score each interaction individually. Upon clicking an interaction on the matrix, a window appeared with the question "If progress is made on target $\mathrm{x}$, how does this influence progress on target y?" (see Fig. 1), where the participants could choose a score from the seven-point typology. The respondents could indicate whether they were uncertain about their score, and they could provide an explanation for the interactions.

The tool automatically calculated all the scores, displaying the results in real time as the participants filled in the matrix. Then, the findings were displayed for debate in plenary: a session held to offer a closer look at interlinkages. These sessions revealed significant variation in participants' scoring. The facilitators of the plenary encouraged debate about the processes behind these interactions, and discussion about how to manage them better. Scores could be adjusted based on the discussion, suggesting a fluidity of interpretation distinct from one that relies on rigidly applying (presumably) relevant indicators. Thus, the approach gathered stakeholders and decision-makers from different sectors to analyze and discuss interactions as part of a learning paradigm.

In the next section, we compare the results from both exercises. To highlight the differences in the data, we created two matrices containing the 13 specific targets that appeared in both studies. These calculations are based on the participant scores minus the values of the non-repeated targets (the complete results of the case studies can be reviewed in 


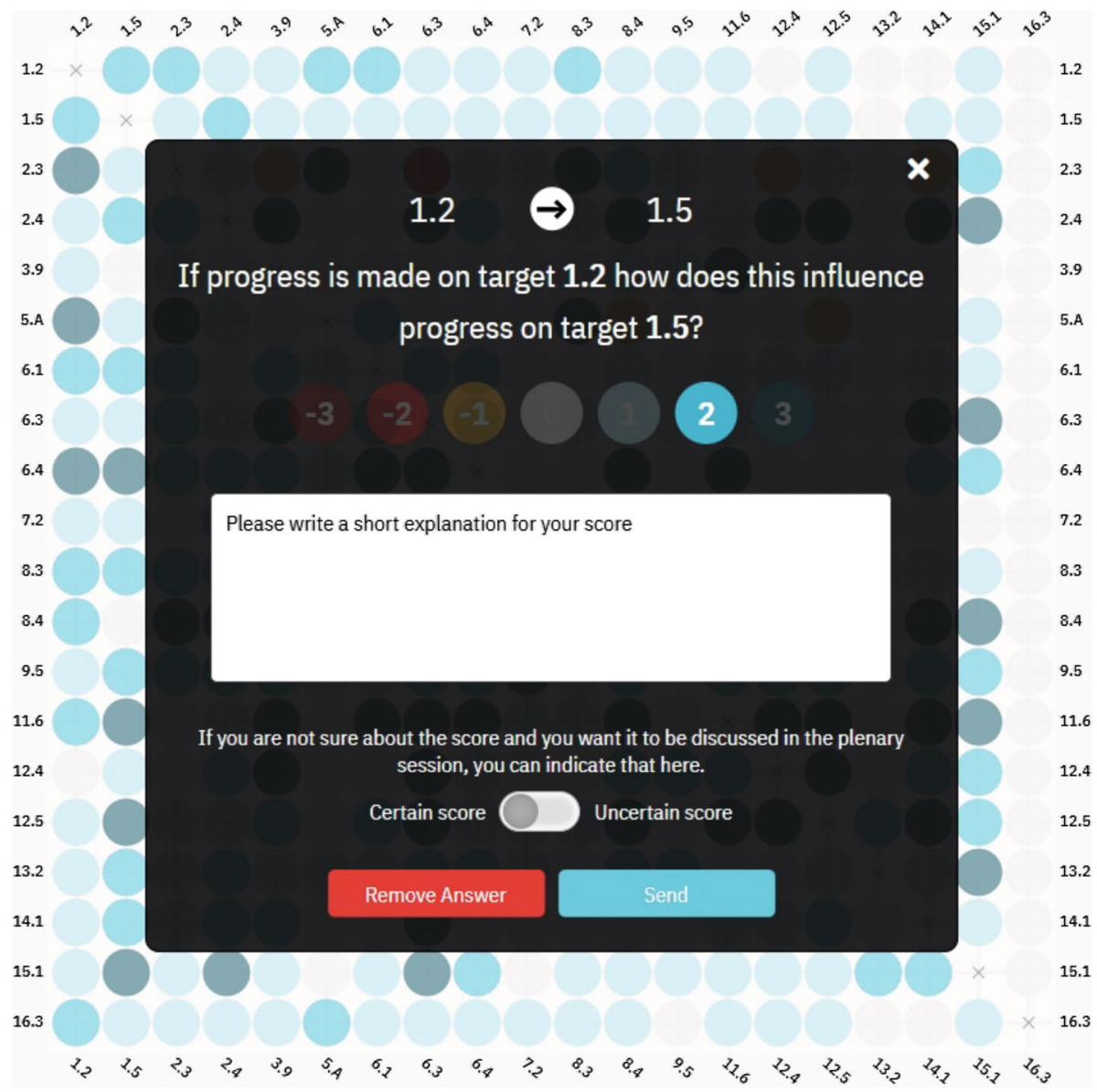

Fig. 1 The SDG Synergies tool. The platform is tailored specifically for the SDGs. The tool allows for the scoring of cross-impact matrices

Appendix 3). All the graphic artwork in the next section was created using the SDG Synergies tool (SEI, 2020).

\section{Findings}

\subsection{First-order interaction values}

One can observe which SDGs positively or negatively affect the rest of the Agenda by examining the first-order interaction values. Neither matrix had SDGs with negative outdegree or in-degree values, suggesting that the targets are not logically inconsistent in either direction. In the national matrix (Fig. 2), the most synergistic target is target 11.6 (Environmental impact of cities), with an out-degree of 29; targets 9.5 (Science and technology) and 12.5 (Waste reduction) share second place with a score of 2.5. By contrast, in the Antioquia matrix (Fig. 3), the highest-ranking target is target 12.5 (Environmental 


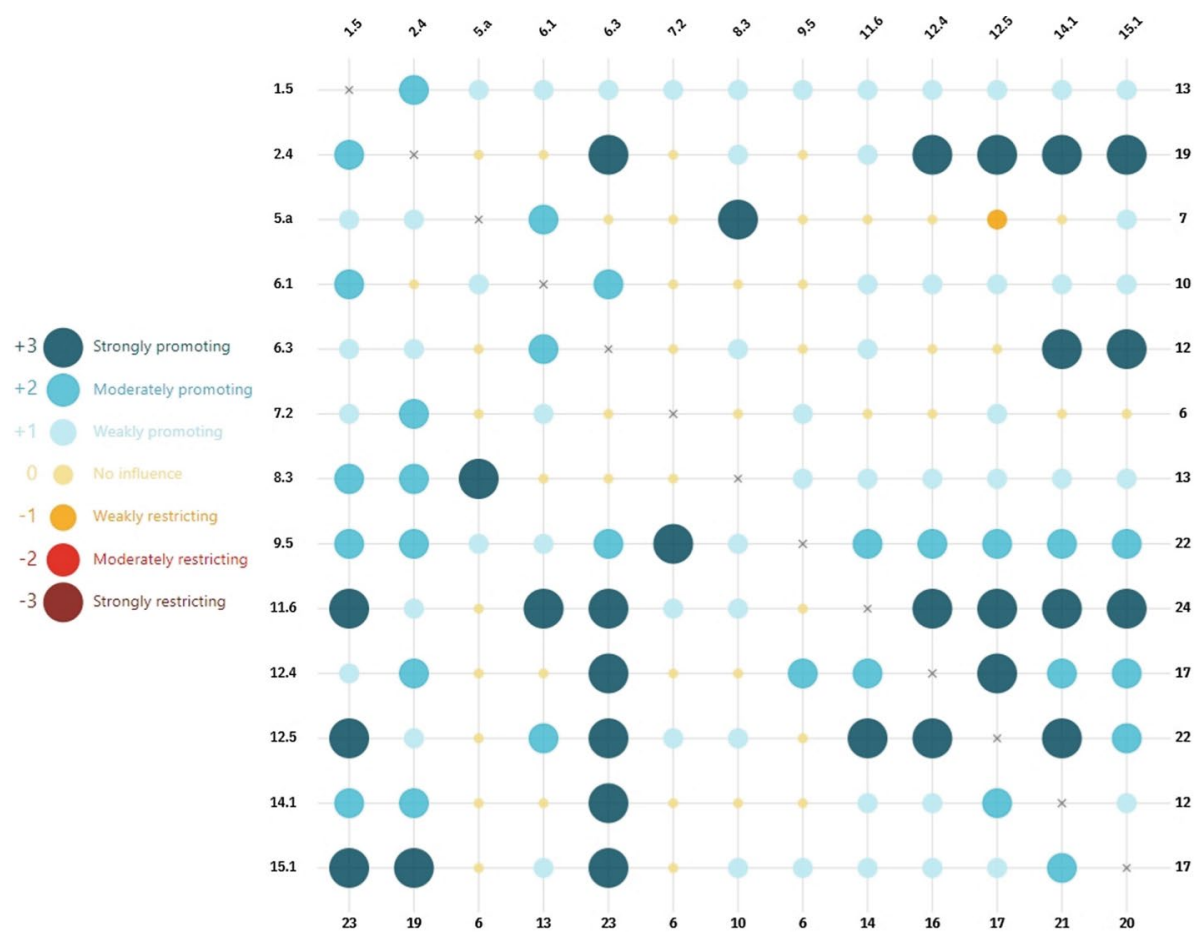

Fig. 2 Cross-impact matrix for the National analysis. The interacting SDGs are shown on the left and top of the matrix. Each dot represents an interaction. The SDGs in the rows correspond to the influencing targets, while targets on the columns are on the receiving end of the interaction. The size of the circle and intensity of the color show the value of the interaction, with larger circles and more intense colors representing higher values (see symbology). Blue circles depict synergies, and red circles depict trade-offs. Yellow dots represent no interaction between the targets. The out-degree and in-degree of each target are placed on the row sum and column sum, respectively

impact of cities), with an out-degree of 24 ; in the second place, target 2.4 (Sustainable agriculture) has a score of 23. Moreover, none of these targets produce trade-offs in their respective matrices, which suggests that they do not cause limiting effects for other targets. High-ranking synergistic targets such as these should be granted priority in the execution of the SDGs because they have the most potential to contribute to the Agenda's achievement (Weitz et al., 2018).

On the other hand, the most influenced targets in the national matrix, ranked by their in-degree, are targets 1.5 (Resilience, scored 25) and 6.3 (Water quality, scored 24). In the Antioquia analysis, the most influenced targets are targets 1.5 (Resilience, scored 26) and 2.4 (Sustainable agriculture, scored 25). In this sense, targets with a high in-degree can make the most advantage of progress on the Agenda as a whole. (Weitz et al., 2018).

Regarding the SDGs displaying trade-offs, in the national matrix, the target 5.a (Women economic empowerment) is the only one showing a negative link - with target 12.5 (Waste reduction). By contrast, in the Antioquia matrix targets 7.2 (Renewable energy), 8.3 (Decent job creation and growth of small-sized enterprises), and 15.1 (Terrestrial and freshwater ecosystems) have negative links. Target 8.3 has the most trade-offs (four). It is crucial to implement these SDGs with caution, and to consider and devise mitigation 


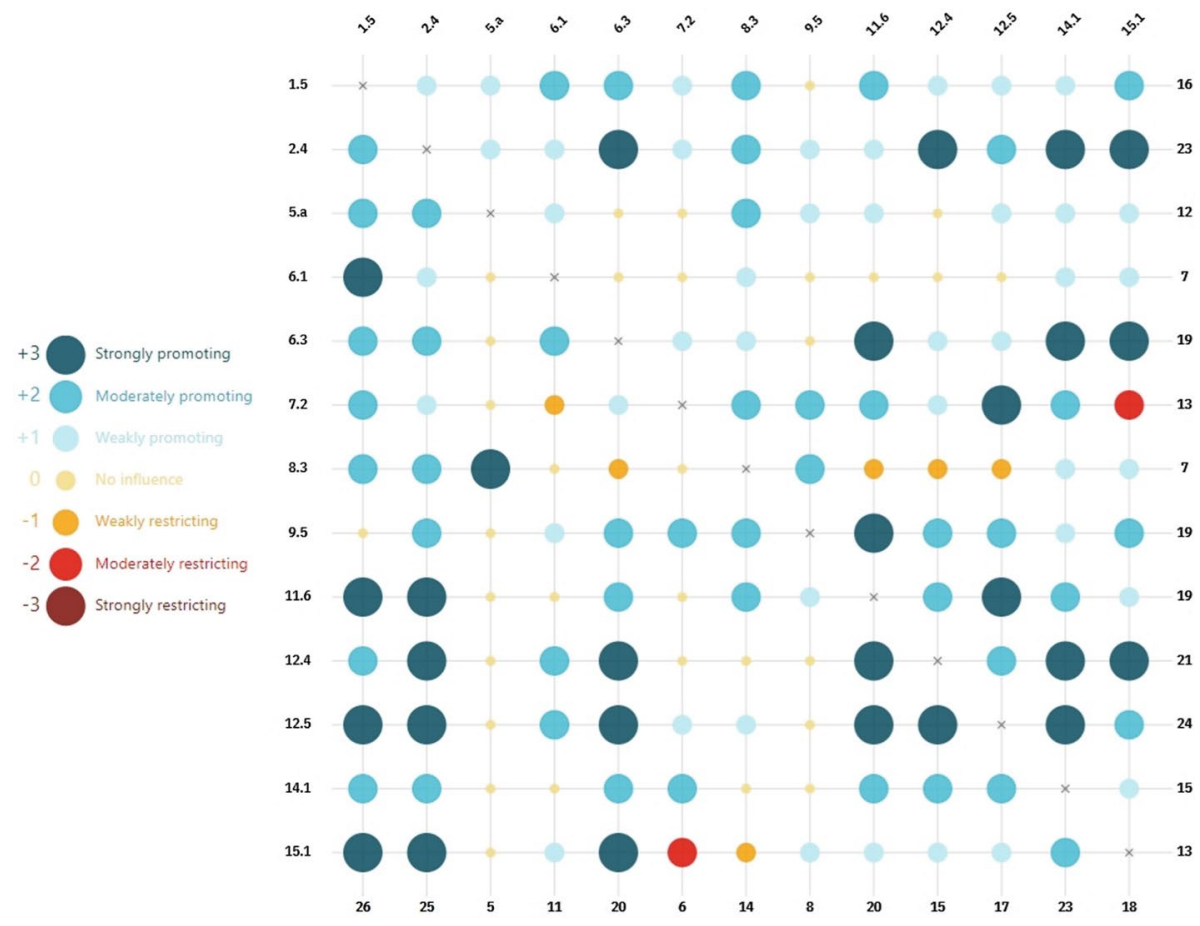

Fig. 3 Cross-impact matrix for the Antioquia analysis. The interacting SDGs are shown on the left and top of the matrix. Each dot represents an interaction. The SDGs in the rows correspond to the influencing targets, while targets on the columns are on the receiving end of the interaction. The size of the circle and intensity of the color show the value of the interaction, with larger circles and more intense colors representing higher values (see symbology). Blue circles depict synergies, and red circles depict trade-offs. Yellow dots represent no interaction between the targets. The out-degree and in-degree of each target are placed on the row sum and column sum, respectively

measures to address their trade-offs. Otherwise, other wider SDG efforts could be compromised (Weitz et al., 2018).

A comparison of both matrices reveals how one specific SDG target can behave differently depending on the exercise and context. For example, in the national analysis, target 8.3 (Decent job creation and growth of small-sized enterprises) has synergies $(+1)$ with targets 11.6 (Environmental impact of cities), 12.4 (Chemical product management), and 12.5 (Waste reduction) (see Fig. 4). By contrast in the Antioquia study, target 8.3 produces trade-offs $(-1)$ with those same three SDGs. These results illustrate that SDG interactions can show stark differences at different scales in the same country.

\subsection{Network analysis: second-order degrees}

There are minor variations in the rankings when comparing first-order out-degrees with the second-order scores (see Table 1). In the national study, targets have very similar rankings in both tables. However, in the first-order ranking, some targets share the same position on the list. For instance, targets 12.5 (Waste reduction) and 9.5 (Science and technology) are both located in the second spot with an out-degree of 25. By contrast, the second-order 


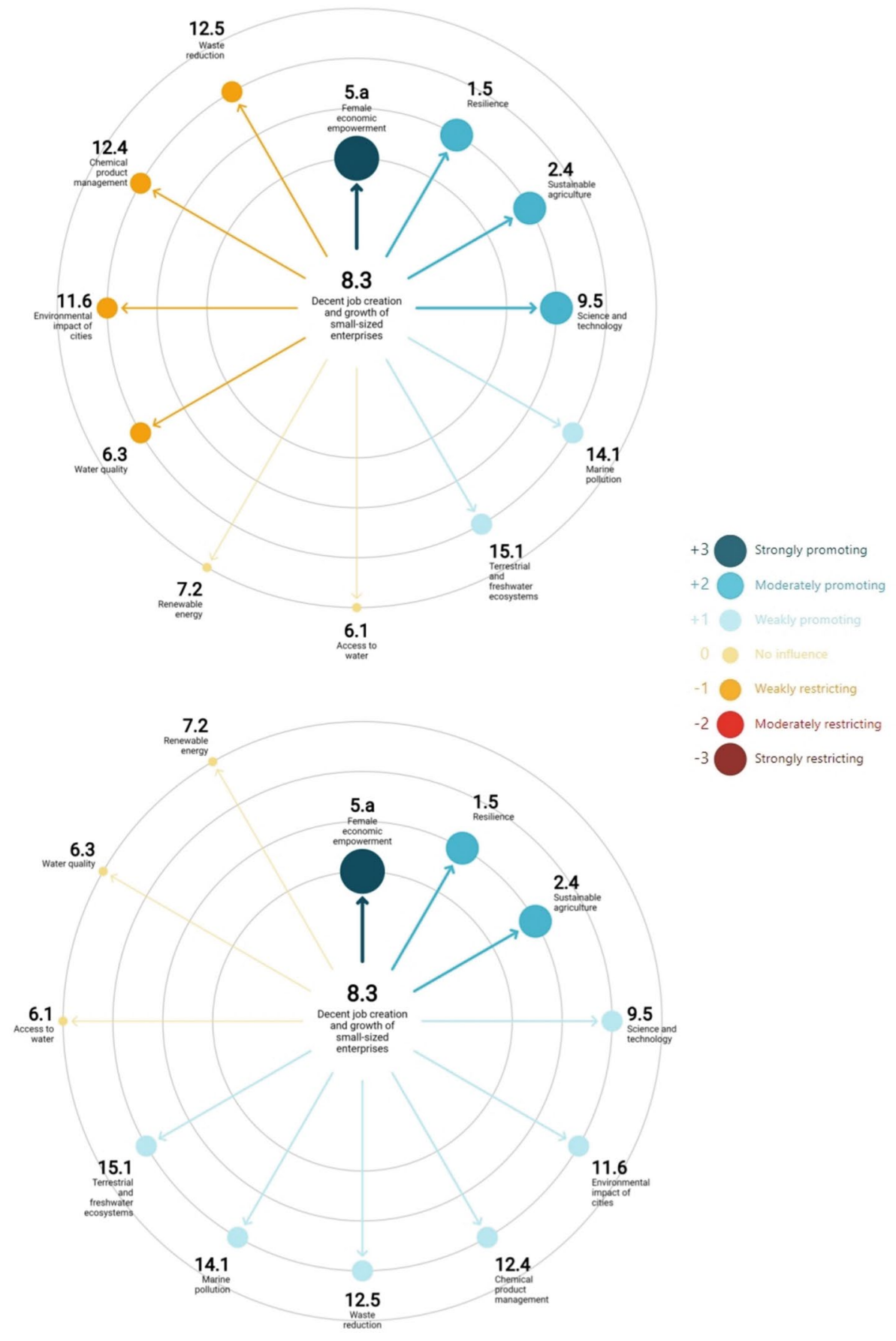

Fig. 4 Satellite graphs of target 8.3 for both case studies. The figure compares the out-degree values of target 8.3 in the Colombia national analysis (top), and Antioquia study (bottom). The size of the circle and intensity of the color show the value of the interaction, with larger circles and more intense colors representing higher values. Interactions with high values are also placed closer to the center of the graph 


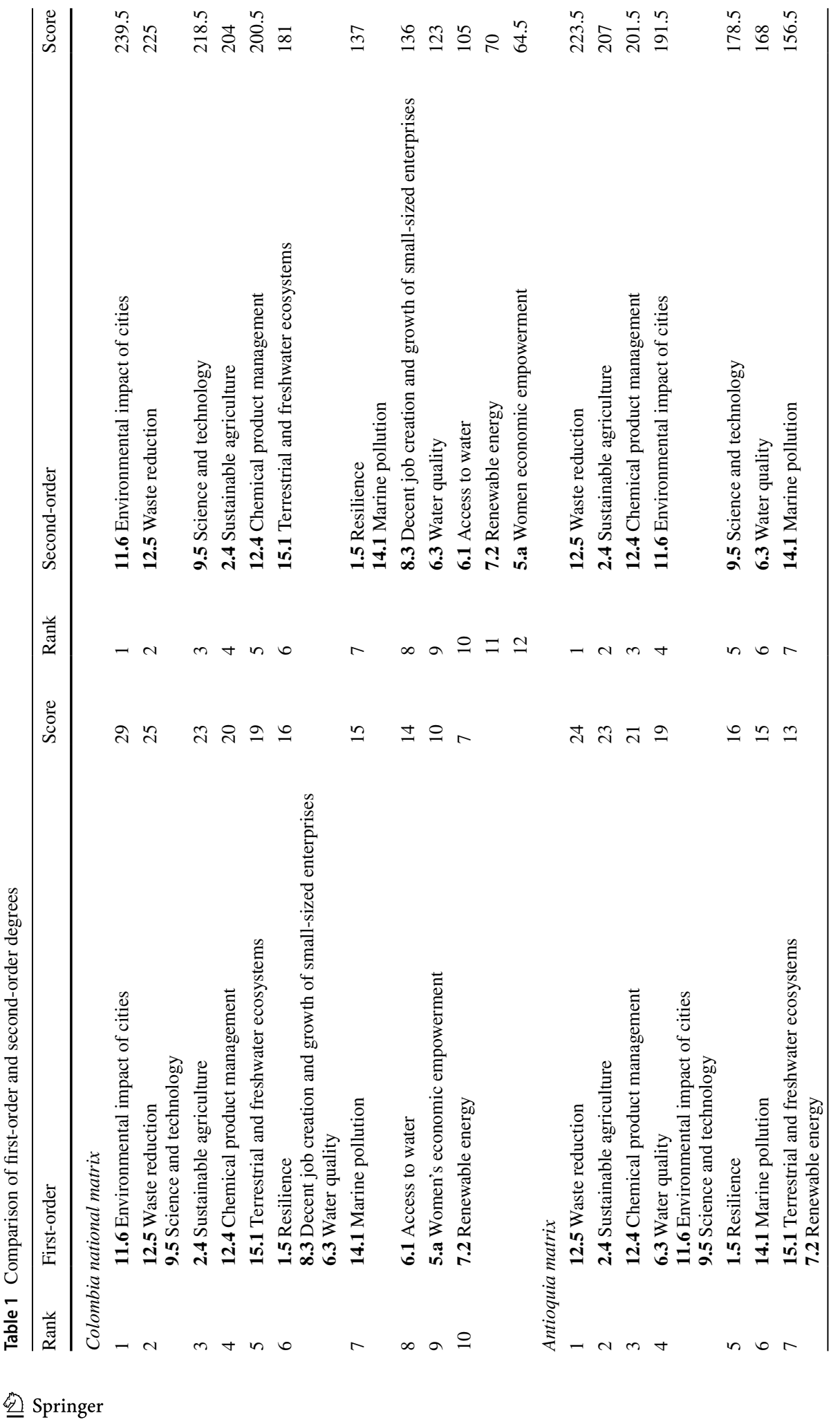




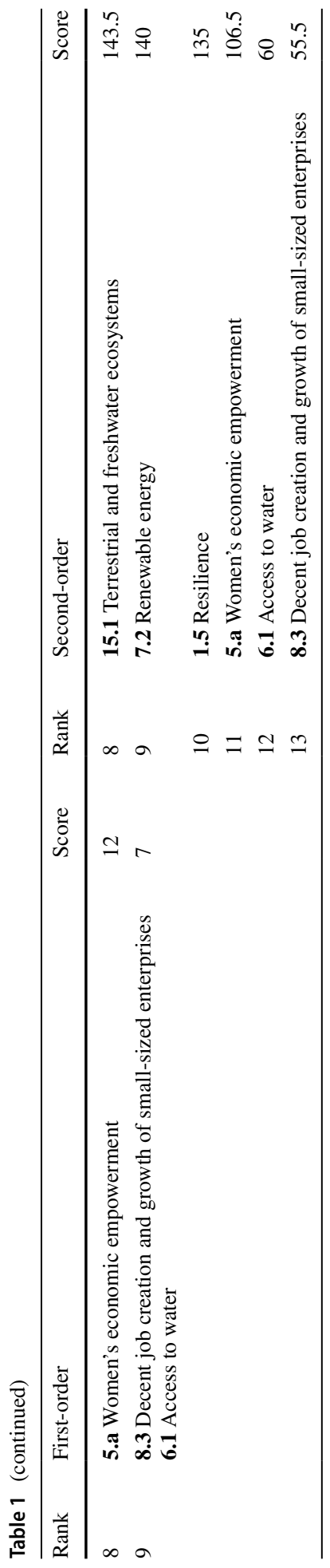


ranking shows more differences between the two scores. It can thus be used as a tiebreaker when prioritizing policy actions. In the Antioquia study, the three most influential SDGs remain unchanged in both rankings (targets 12.5, Waste reduction; 2.4, Sustainable agriculture; and 12.4, Chemical product management). However, the Antioquia calculations show more variance in the rankings than the national counterpart calculations.

In sum, evident differences emerge in the results of the two exercises. For instance, the most obvious differences can be seen in the results concerning target 8.3 (Decent job creation and growth of small-sized enterprises), which generates synergies with targets 11.6 (Environmental impact of cities), 12.4 (Chemical product management), and 12.5 (Waste reduction) in the national analysis, while producing trade-offs in Antioquia with those same targets. As this example shows, one specific SDG target can have contrasting interlinkages with the same pairs of targets when analyzed at different scales. This finding implies that contextual and scale-related differences can define the occurrence of synergies or trade-offs. This suggests that characterizations at the local scale can produce a more complex network, with discussion among stakeholders revealing synergies and trade-offs between specific interventions in that territory, in contrast to more abstract discussion that may emerge at a national scale. As one of the first comparisons between national and subnational SDG interactions, our study confirms assertions by prior researchers (JiménezAceituno et al., 2020; Reed et al., 2015; Stephens et al., 2018) that the nature SDG interactions can vary significantly based on local contexts and realities.

\section{Discussion}

To date, most attention has been on the national scale for SDG interaction analyses, creating a dearth of studies measuring interactions at subnational levels. In this paper we argue that there is a need to deploy methods that are not limited by the comparative lack of data availability in subnational settings - particularly in light of the premise that the nature of interactions is context dependent, the findings that have surfaced in our case study, and the absence of credible subnational-level data. We address this issue by using the SDG Synergies approach to account for interlinkages at two scales of analysis in Colombia, the national and the regional. The application of the method brought together a wide range of key stakeholders behind the implementation of the SDGs at both levels of governance. From a soft systems thinking perspective, the observed interactions are based on information that these actors will use to decide when executing the SDGs, thus driving the implementation of the Agenda. In this sense, according to Weitz et al. (2018) and Nilsson and Weitz (2019), the results from the approach can be used as a basis for policy coherence efforts to enhance the implementation of the SDGs.

In this regard, the use of soft systems thinking facilitated dialogue among various actors involved in the implementation of the Agenda. As Nilsson and Weitz (2019) point out, it is essential to use methods in which SDG interactions are calculated in ways that account for "the diverse values, world views, and legitimate interests of different stakeholders. These will influence how issues and knowledge are interpreted and used in political processes," These authors argue that an SDGs interactions-assessment framework is most useful to governments if the process takes place within the policy-making processes because the different institutions or government departments that partake in it will "...come together and jointly identify how they relate to each other in terms of their respective priorities, and on what topics negotiations are required to manage trade-offs," The implication is that through 
the discussion process of soft systems thinking methodologies, the different subjective understandings of how the SDGs interact will be shared among the participants, influencing the stakeholders' worldviews, and fostering cooperation among them.

Our findings also show that SDG interactions can take very different forms when observed at different scales. The interlinkages for both case studies were assessed in Colombia, in a shared territory and policy-making space. The contrasting results of the studies at national and department levels begs the question: What are the implications for policy coherence between national- and Antioquia-level policies? For instance, in terms of policy prioritization, the most influential target in the national matrix is 11.6 (Environmental impact of cities); in Antioquia, it is 12.5 (Waste reduction). The question then follows as to whether a country-level policy concerning target 11.6 would have the same catalytic effect in the department of Antioquia as in Colombia as a country. Similarly, we can ask if national policies can produce unequal development in subnational territories, affecting some regions positively and others negatively-creating trade-offs. This possibility is illustrated by target 8.3 (Decent job creation and growth of small-sized enterprises), which has a positive effect with the rest of the Agenda at the national scale, while generating trade-offs in Antioquia when interacting with four targets: 6.3 (Water quality), 11.6 (Environmental impact of cities), 12.4 (Chemical product management), and 12.5 (Waste reduction). A closer examination of the policy actions behind these trade-offs would be needed to establish safeguards to mitigate these negative effects, and to make sure that the Colombian national SDG strategy and Antioquia-level policies align. On the other hand, Liu (2017) has suggested that local SDG efforts have the potential to generate interactions at scales larger than the territories in which they are implemented. Thus, these same questions emerge in an opposite direction. One must ask whether Antioquia-level SDG actions can have an influence outside that department's boundaries.

These are important concerns that create a higher level of complexity in enhancing policy coherence for SDG implementation in Colombia. Although the results are specific to Colombia, other scale-related differences are likely to manifest themselves elsewhere. It is thus paramount for other SDG researchers and practitioners to use strategies that enhance policy coherence across scales.

In this regard, the literature has already pointed out the need to apply multilevel governance strategies to align SDG efforts (see Fenton \& Gustafsson, 2017; Meuleman \& Niestroy, 2015; Sospedra \& Martin, 2005). However, nothing has been said about how to effectively address differences in SDG interactions across-scale once such differences have been revealed and acknowledged. Along these lines, from a soft systems thinking perspective, SDG interactions can be managed most effectively not by technical solutions in isolation, but through the participation, discussion, and consensus of involved stakeholders.

Therefore, there needs to be a participatory evaluation between stakeholders at different levels of governance about how the decisions at one scale of implementation can affect another. We believe that there is substantial potential in soft systems thinking methodologies for creating such spaces for discussion, where various stakeholders of different scales of government share, debate, and, one hopes, reach agreement on their mutual interests and various worldviews-influencing the workings of the governance systems that determine progress on the SDGs. Furthermore, the continued use of these methodologies in policy making for the SDGs would allow for adaptative management of policies as decisions adjust in the process of assessing unexpected effects and emerging issues.

However, the methodology in its current state does not consider how interactions in different places, regions, and scales affect each other. This process would entail gathering actors from various contexts and geographies to create a multi-regional matrix that 
accounts for the effects of SDG implementation across territories. In this regard, the development and application of a soft methodology that specifically tackles cross-scale SDG interactions is a topic for further research. In fact, this cross-scale harmonization effort may provide an opportunity to coordinate soft systems thinking with other emerging SDGinteraction approaches, including hard systems thinking methods. Hard systems thinking approaches claim some predictive capacity as to how SDGs will interact at the national scale, based on a paradigm that relies on existing structures of power and authority. Soft systems thinking approaches could use this as a jumping-off point. Rather than starting the matrix construction process from a blank slate, participants could discuss how to adjust scores derived from these predictions in the context of specific SDG targets, specific scales, and specific opportunities to adjust existing structure toward the overall SSM objective of "change to bring about improvement" in the context of the Agenda 2030. Such integration could offer insights into specific policy reforms, in addition to aiding prioritization, collaboration, and negotiation.

Finally, the SDG Synergies approach can be improved by integrating the participativeiterative methodologies of OR and other soft systems thinking, such as Checkland's SSM. Incorporating such methodologies would entail exploring how cross-impact analysis captures and modifies respondents' "appreciative systems," and proposing new procedures based on this theoretical grounding.

\section{Conclusions}

Understanding the synergies and trade-offs of the interactions among the Sustainable Development Goals requires thinking about the ramifications at the specific scales where implementation occurs to achieve the aims of individual targets, SDGs, and the full menu of elements of the 2030 Agenda. Nevertheless, our literature review shows that most studies use approaches that rely on data that provide information from the country level only. Methodologies that rely almost exclusively on information from national scales assume that aggregate patterns of progress at the national level hold true for subnational scales, too- an assumption that is undercut by our findings.

To the best of our knowledge, our study is one of the first of its kind to examine the interactions of selected SDGs and targets at the national and subnational scales. Our study looked at the synergies and trade-offs for both Colombia, at the national scale, and for one of its departments, Antioquia, at the regional scale. Our findings show profound differences in the synergies and trade-offs at these two different scales. For example, target 8.3 (Decent job creation and growth of small-sized enterprises) generates synergies with targets 11.6 (Environmental impact of cities), 12.4 (Chemical product management), and 12.5 (Waste reduction) at the national level but trade-offs at the department level with the same targets. These findings show that closer examination of the policy actions behind these differences is needed to mitigate the negative trade-offs from policy measures, and to make sure national and regional level strategies are aligned.

More broadly, we argue that subnational assessments of SDG interactions are vital for the effective implementation of the Agenda. Methods and tools that can analyze SDGs and target interactions at the subnational scale must be developed—and soon, if the 2030 Agenda target date is to be met.

To tackle this gap, we propose the use of soft systems thinking methodologies as a way forward. Such methodologies are not limited by the availability of official data at any 
scale. Our own study used the SDG Synergies approach, a soft systems thinking method, to account for SDG interactions at the national and subnational scales, and, as such, it demonstrates the viability of the use of such a system in the absence of available data.

Moreover, our wider examination of soft systems thinking methodologies vis à vis other approaches leads us to conclude that such systems are a preferable means for characterizing SDG interactions, regardless of the scale of analysis. This is because soft systems thinking can create spaces for discussion and agreement among stakeholders; this is crucial for confronting the structures of power and bureaucracy behind the implementation of the SDGs. Our research shows that such power structures can underlie the patterns and mechanisms identified through hard systems thinking methodologies, which are then characterized as SDG interactions. In this context, the different understanding of social reality that emerges from a hard or soft systems approaches is important. If we confuse the results of hard approaches with an objective social reality about the Agenda, we may miss opportunities to transform how these interactions behave through soft systems thinking. Moreover, the potential for cross-scale interactions raises important questions for policy coherence when implementing the SDGs at different governance levels, even within the same country. We propose further developing and using soft systems thinking methodologies to manage political conflict and cooperation in SDG implementation.

\section{Appendix 1: Participants}

\begin{tabular}{|c|c|c|c|}
\hline \multicolumn{4}{|c|}{ Entities and organizations that participated in the national study } \\
\hline \multirow{9}{*}{$\begin{array}{l}\text { National government } \\
\text { entities }\end{array}$} & Presidency & Academia & University of the Andes \\
\hline & $\begin{array}{l}\text { National Department of } \\
\text { Planning }\end{array}$ & & Externado University \\
\hline & $\begin{array}{l}\text { Ministry of Environ- } \\
\text { ment and Sustainable } \\
\text { Development }\end{array}$ & & $\begin{array}{l}\text { Sustainable Development } \\
\text { Goals Center for Latin } \\
\text { America and the Carib- } \\
\text { bean (CODS) }\end{array}$ \\
\hline & $\begin{array}{l}\text { National Unit for Risk } \\
\text { Disaster Management } \\
\text { (UNGRD) }\end{array}$ & & $\begin{array}{l}\text { Pontifical Xaverian Uni- } \\
\text { versity }\end{array}$ \\
\hline & $\begin{array}{l}\text { National Agency for } \\
\text { Land Management } \\
\text { (ANT) }\end{array}$ & Industrial sector & Nutresaal \\
\hline & $\begin{array}{l}\text { Social Protection } \\
\text { Department (DPS) }\end{array}$ & & $\begin{array}{l}\text { National Association for } \\
\text { Industry (ANDI) }\end{array}$ \\
\hline & $\begin{array}{l}\text { Mining and Energy } \\
\text { Planning Unit (UPME) }\end{array}$ & & $\begin{array}{l}\text { National Federation of } \\
\text { Coffee Growers of } \\
\text { Colombia (Fedecacao) }\end{array}$ \\
\hline & $\begin{array}{l}\text { National Department of } \\
\text { Statistics (DANE) }\end{array}$ & & $\begin{array}{l}\text { Fund for Financing the } \\
\text { Agricultural Sector } \\
\text { (FINAGRO) }\end{array}$ \\
\hline & $\begin{array}{l}\text { National Department } \\
\text { of Science, Technol- } \\
\text { ogy and Innovation } \\
\text { (Colciencias) }\end{array}$ & & $\begin{array}{l}\text { Colombian Association of } \\
\text { Miners (ACM) }\end{array}$ \\
\hline
\end{tabular}


Entities and organizations that participated in the national study

Comptroller

Ministry for Agriculture and Rural Development (Minagricultura)

Ministry for Housing, City and Territory (Minvivenda)

Ministry for Defence (Mindefensa)

Ministry for Health and Social Protection (Minsalud)

Ministry for Employment (Mintrabajo)

Institute for Environmental and Meteorological Studies (IDEAM)

National Natural Parks System (PNN)

National Agency for Environmental Licensing (ANLA)

National Commission for Drinking Water and Basic Sanitation (CRA)

Amazonian Institute for Scientific Research (SINCHI)
Subnational government

District Secretariat for Planning

District Secretariat for Health

District Secretariat for Environment

Association of Regional Autonomous Corporations for Sustainable Development

(ASOCARS)

Government of the Department of Cundinamarca

Civil Society/NGO

World Wide Fund for Nature (WWF)

Fondo Acción (Action Fund)

National Network of Youth for Environment (Red Nacional Jóvenes de Ambiente)

Cómo Vamos Cities Network

International organizations

United Nations Environment Programme (UNEP)

United Nations Industrial Development Organization (UNIDO)

United Nations Office on Drugs and Crime (UNODC)

Food and Agriculture Organization of the United Nations (FAO)

United Nations Population Fund (UNFPA)

United Nations Development Programme (UNDP) 
Entities and organizations that participated in the Antioquia study

\begin{tabular}{|c|c|c|c|}
\hline \multirow[t]{13}{*}{$\begin{array}{l}\text { Antioquia government } \\
\text { entities }\end{array}$} & $\begin{array}{l}\text { Medellín City Govern- } \\
\text { ment }\end{array}$ & Academia & EAFIT University \\
\hline & $\begin{array}{l}\text { Government of the } \\
\text { Department of Antio- } \\
\text { quia }\end{array}$ & & $\begin{array}{l}\text { Sustainable Development } \\
\text { Goals Center for Latin } \\
\text { America and the Carib- } \\
\text { bean (CODS) }\end{array}$ \\
\hline & $\begin{array}{l}\text { Forum for the Progress } \\
\text { of South America } \\
\text { (PROSUR) }\end{array}$ & & University of Antioquia \\
\hline & $\begin{array}{l}\text { Region corporation } \\
\text { (Corporación Región) }\end{array}$ & & $\begin{array}{l}\text { Pontifical Bolivarian } \\
\text { University }\end{array}$ \\
\hline & $\begin{array}{l}\text { Regional Autonomous } \\
\text { Corporation for } \\
\text { Sustainable Develop- } \\
\text { ment of Antioquia } \\
\text { (CorAntioquia) }\end{array}$ & Industrial sector & Argos cement factory \\
\hline & $\begin{array}{l}\text { Regional Autonomous } \\
\text { Corporation for } \\
\text { Sustainable Devel- } \\
\text { opment of Urabá } \\
\text { (CorpoUrabá) }\end{array}$ & & $\begin{array}{l}\text { Public Enterprises of } \\
\text { Medellín (EPM) }\end{array}$ \\
\hline & $\begin{array}{l}\text { Metropolitan Area of } \\
\text { the Aburrá Valley } \\
\text { (ÑMVA) }\end{array}$ & & ISAGEN \\
\hline & $\begin{array}{l}\text { Antioquia's Corpora- } \\
\text { tion for Environment } \\
\text { (CORAMA) }\end{array}$ & & $\begin{array}{l}\text { National Association for } \\
\text { Industry (ANDI) }\end{array}$ \\
\hline & $\begin{array}{l}\text { Corporación Cuenca } \\
\text { Verde (Cuenca Verde }\end{array}$ & Other entities & $\begin{array}{l}\text { World Wide Fund for } \\
\text { Nature (WWF) }\end{array}$ \\
\hline & Corporation) & & ProAntioquia \\
\hline & & & $\begin{array}{l}\text { Global Green Growth } \\
\text { Institute (GGGI) }\end{array}$ \\
\hline & & & "Aburrá Cómo Vamos" \\
\hline & & & United Nations (UN) \\
\hline
\end{tabular}

Number of participants per institution type

\begin{tabular}{lll}
\hline Type of institution & Colombia national workshop & Antioquia regional workshop \\
\hline Government & 59 & 22 \\
International organizations & 15 & 8 \\
Academia & 11 & 18 \\
Industrial sector & 3 & 5 \\
Civil society & 12 & 7 \\
Total & 100 & 60 \\
\hline
\end{tabular}




\section{Appendix 2: SDGs addressed}

SDG

Colombia national analysis

1.2

2.4
Description

By 2030, reduce at least by half the proportion of men, women and children of all ages living in poverty in all its dimensions according to national definitions

By 2030, build the resilience of the poor and those in vulnerable situations and reduce their exposure and vulnerability to climate-related extreme events and other economic, social and environmental shocks and disasters

By 2030, double the agricultural productivity and incomes of small-scale food producers, in particular women, indigenous peoples, family farmers, pastoralists and fishers, including through secure and equal access to land, other productive resources and inputs, knowledge, financial services, markets and opportunities for value addition and non-farm employment

By 2030, ensure sustainable food production systems and implement resilient agricultural practices that increase productivity and production, that help maintain ecosystems, that strengthen capacity for adaptation to climate change, extreme weather, drought, flooding and other disasters and that progressively improve land and soil quality

By 2030, substantially reduce the number of deaths and illnesses from hazardous chemicals and air, water and soil pollution and contamination

Undertake reforms to give women equal rights to economic resources, as well as access to ownership and control over land and other forms of property, financial services, inheritance and natural resources, in accordance with national laws

By 2030, achieve universal and equitable access to safe and affordable drinking water for all

By 2030, improve water quality by reducing pollution, eliminating dumping and minimizing release of hazardous chemicals and materials, halving the proportion of untreated wastewater and substantially increasing recycling and safe reuse globally

By 2030, substantially increase water-use efficiency across all sectors and ensure sustainable withdrawals and supply of freshwater to address water scarcity and substantially reduce the number of people suffering from water scarcity

By 2030, increase substantially the share of renewable energy in the global energy mix 


SDG Description

8.3

9.5

Antioquia department analysis

\section{5}

Promote development-oriented policies that support productive activities, decent job creation, entrepreneurship, creativity and innovation, and encourage the formalization and growth of micro-, small- and medium-sized enterprises, including through access to financial services

Improve progressively, through 2030, global resource efficiency in consumption and production and endeavour to decouple economic growth from environmental degradation, in accordance with the 10 Year Framework of Programmes on Sustainable Consumption and Production, with developed countries taking the lead

Improve progressively, through 2030, global resource efficiency in consumption and production and endeavour to decouple economic growth from environmental degradation, in accordance with the 10 Year Framework of Programmes on Sustainable Consumption and Production, with developed countries taking the lead

By 2030, reduce the adverse per capita environmental impact of cities, including by paying special attention to air quality and municipal and other waste management

By 2020, achieve the environmentally sound management of chemicals and all wastes throughout their life cycle, in accordance with agreed international frameworks, and significantly reduce their release to air, water and soil in order to minimize their adverse impacts on human health and the environment

By 2030, substantially reduce waste generation through prevention, reduction, recycling and reuse

Integrate climate change measures into national policies, strategies and planning

By 2025, prevent and significantly reduce marine pollution of all kinds, in particular from land-based activities, including marine debris and nutrient pollution

By 2020, ensure the conservation, restoration and sustainable use of terrestrial and inland freshwater ecosystems and their services, in particular forests, wetlands, mountains and drylands, in line with obligations under international agreements

Promote the rule of law at the national and international levels and ensure equal access to justice for all

By 2030, build the resilience of the poor and those in vulnerable situations and reduce their exposure and vulnerability to climate-related extreme events and other economic, social and environmental shocks and disasters 
SDG

2.4

$5 . \mathrm{a}$

6.1

6.3

6.6

\section{Description}

By 2030, ensure sustainable food production systems and implement resilient agricultural practices that increase productivity and production, that help maintain ecosystems, that strengthen capacity for adaptation to climate change, extreme weather, drought, flooding and other disasters and that progressively improve land and soil quality

Undertake reforms to give women equal rights to economic resources, as well as access to ownership and control over land and other forms of property, financial services, inheritance and natural resources, in accordance with national laws

By 2030, achieve universal and equitable access to safe and affordable drinking water for all

By 2030, improve water quality by reducing pollution, eliminating dumping and minimizing release of hazardous chemicals and materials, halving the proportion of untreated wastewater and substantially increasing recycling and safe reuse globally

By 2020 , protect and restore water-related ecosystems, including mountains, forests, wetlands, rivers, aquifers and lakes

By 2030, increase substantially the share of renewable energy in the global energy mix

Promotedevelopment-oriented policies that support productive activities, decent job creation, entrepreneurship, creativity and innovation, and encourage the formalization and growth of micro-, small- and medium-sized enterprises, including through access to financial services

Improve progressively, through 2030, global resource efficiency in consumption and production and endeavour to decouple economic growth from environmental degradation, in accordance with the 10 Year Framework of Programmes on Sustainable Consumption and Production, with developed countries taking the lead

By 2030, reduce the adverse per capita environmental impact of cities, including by paying special attention to air quality and municipal and other waste management

By 2020, achieve the environmentally sound management of chemicals and all wastes throughout their life cycle, in accordance with agreed international frameworks, and significantly reduce their release to air, water and soil in order to minimize their adverse impacts on human health and the environment

By 2030, substantially reduce waste generation through prevention, reduction, recycling and reuse

Improve education, awareness-raising and human and institutional capacity on climate change mitigation, adaptation, impact reduction and early warning 


\begin{tabular}{ll}
\hline SDG & Description \\
\hline 14.1 & By 2025, prevent and significantly reduce marine \\
& pollution of all kinds, in particular from land-based \\
& activities, including marine debris and nutrient \\
& pollution \\
& By 2020, ensure the conservation, restoration and \\
& sustainable use of terrestrial and inland freshwater \\
& ecosystems and their services, in particular forests, \\
& wetlands, mountains and drylands, in line with \\
& obligations under international agreements \\
&
\end{tabular}

\section{Appendix 3: Results of both studies}

\begin{tabular}{|c|c|c|c|c|c|}
\hline Rank & Out-degree & Score & Rank & In-degree & Score \\
\hline \multicolumn{6}{|c|}{ Colombia national matrix: first-order values } \\
\hline 1 & $\begin{array}{l}\text { 8.4 Sustainable } \\
\text { consumption } \\
\text { and produc- } \\
\text { tion } \\
\text { 11.6 Envi- } \\
\text { ronmental } \\
\text { impact of } \\
\text { cities }\end{array}$ & 35 & 1 & $\begin{array}{l}\text { 1.5 Resilience } \\
\mathbf{1 5 . 1} \text { Ter- } \\
\text { restrial and } \\
\text { freshwater } \\
\text { ecosystems }\end{array}$ & 32 \\
\hline 2 & $\begin{array}{r}\text { 12.5 Waste } \\
\text { reduction }\end{array}$ & 32 & 2 & $\begin{array}{c}\text { 6.3 Water } \\
\text { quality }\end{array}$ & 31 \\
\hline 3 & $\begin{array}{l}\text { 9.5 Science and } \\
\text { technology }\end{array}$ & 31 & 3 & $\begin{array}{l}\text { 1.2 Reduce } \\
\text { poverty } \\
2.4 \text { Sustainable } \\
\text { agriculture }\end{array}$ & 30 \\
\hline 4 & $\begin{array}{l}\text { 2.4 Sustainable } \\
\text { agriculture }\end{array}$ & 30 & 4 & $\begin{array}{l}\text { 3.9 Deaths } \\
\text { from con- } \\
\text { tamination }\end{array}$ & 29 \\
\hline 5 & $\begin{array}{l}\text { 6.4 Water-use } \\
\text { efficiency }\end{array}$ & 30 & 5 & $\begin{array}{l}\text { 2.3 Agriculture } \\
\text { and land } \\
\text { 8.4 Sustainable } \\
\text { consumption } \\
\text { and produc- } \\
\text { tion }\end{array}$ & 27 \\
\hline 6 & $\begin{array}{l}\text { 15.1 Ter- } \\
\text { restrial and } \\
\text { freshwater } \\
\text { ecosystems }\end{array}$ & 29 & 6 & $\begin{array}{l}\text { 14.1 Marine } \\
\text { pollution }\end{array}$ & 26 \\
\hline 7 & $\begin{array}{l}\text { 12.4 Chemi- } \\
\text { cal product } \\
\text { management } \\
\text { 13.2 Climate } \\
\text { change and } \\
\text { national poli- } \\
\text { cies }\end{array}$ & 23 & 7 & $\begin{array}{l}\text { 11.6 Envi- } \\
\text { ronmental } \\
\text { impact of } \\
\text { cities } \\
\mathbf{1 2 . 5} \text { Waste } \\
\text { reduction }\end{array}$ & 24 \\
\hline
\end{tabular}




\begin{tabular}{|c|c|c|c|c|c|}
\hline Rank & Out-degree & Score & Rank & In-degree & Score \\
\hline 8 & $\begin{array}{l}\text { 1.2 Reduce } \\
\text { poverty } \\
6.1 \text { Access to } \\
\text { water } \\
6.3 \text { Water } \\
\text { quality } \\
\text { 8.3 Decent job } \\
\text { creation and } \\
\text { growth of } \\
\text { small-sized } \\
\text { enterprises }\end{array}$ & 20 & 8 & $\begin{array}{l}\text { 6.1 Access to } \\
\text { water } \\
\text { 6.4 Water-use } \\
\text { efficiency }\end{array}$ & 23 \\
\hline 9 & 1.5 Resilience & 19 & 9 & $\begin{array}{l}\text { 12.4 Chemi- } \\
\text { cal product } \\
\text { management }\end{array}$ & 18 \\
\hline 10 & $\begin{array}{l}\text { 16.3 Equal } \\
\text { access to } \\
\text { justice }\end{array}$ & 18 & 10 & $\begin{array}{l}\text { 8.3 Decent job } \\
\text { creation and } \\
\text { growth of } \\
\text { small-sized } \\
\text { enterprises }\end{array}$ & 17 \\
\hline 11 & $\begin{array}{l}\text { 14.1 Marine } \\
\text { pollution }\end{array}$ & 16 & 11 & $\begin{array}{l}\text { 5.a Women's } \\
\text { economic } \\
\text { empower- } \\
\text { ment }\end{array}$ & 15 \\
\hline 12 & $\begin{array}{l}\text { 2.3 Agriculture } \\
\text { and land } \\
\text { 5.a Women's } \\
\text { economic } \\
\text { empower- } \\
\text { ment }\end{array}$ & 14 & 12 & $\begin{array}{l}\text { 9.5 Science and } \\
\text { technology }\end{array}$ & 12 \\
\hline 13 & $\begin{array}{l}\text { 7.2 Renewable } \\
\text { energy }\end{array}$ & 8 & 13 & $\begin{array}{l}\text { 7.2 Renewable } \\
\text { energy }\end{array}$ & 11 \\
\hline \multirow[t]{2}{*}{14} & $\begin{array}{l}\text { 3.9 Deaths } \\
\text { from con- } \\
\text { tamination }\end{array}$ & 7 & 14 & $\begin{array}{l}\text { 13.2 Climate } \\
\text { change and } \\
\text { national poli- } \\
\text { cies }\end{array}$ & 4 \\
\hline & & & 15 & $\begin{array}{l}\text { 16.3 Equal } \\
\text { access to } \\
\text { justice }\end{array}$ & 0 \\
\hline \multicolumn{6}{|c|}{ Antioquia study: first order values } \\
\hline 1 & $\begin{array}{l}\text { 2.4 Sustainable } \\
\text { agriculture }\end{array}$ & 28 & 1 & 1.5 Resilience & 32 \\
\hline 2 & $\begin{array}{l}\text { 12.5 Waste } \\
\text { reduction }\end{array}$ & 27 & 2 & $\begin{array}{l}\text { 2.4 Sustainable } \\
\text { agriculture }\end{array}$ & 29 \\
\hline 3 & $\begin{array}{l}\text { 6.3 Water } \\
\text { quality } \\
\text { 12.4 Chemi- } \\
\text { cal product } \\
\text { management }\end{array}$ & 24 & 3 & $\begin{array}{l}\text { 14.1 Marine } \\
\text { pollution }\end{array}$ & 26 \\
\hline
\end{tabular}




\begin{tabular}{llllll}
\hline Rank & Out-degree & Score & Rank & In-degree & Score \\
\hline 4 & $\begin{array}{l}\text { 6.6 Water } \\
\text { ecosystems }\end{array}$ & 22 & 4 & $\mathbf{6 . 3}$ Water & 25 \\
& $\begin{array}{l}\mathbf{1 1 . 6} \text { Envi- } \\
\text { ronmental }\end{array}$ & & & & \\
& $\begin{array}{l}\text { impact of } \\
\text { cities }\end{array}$ & & & & \\
& & & &
\end{tabular}

13.3 Awareness

and capacity

for climate

change

$5 \quad 9.5$ Science and 21

5

11.6 Envi-

technology

ronmental

impact of

cities

6

1.5 Resilience $\quad 20$

6

6.6 Water

22

ecosystems

15.1 Ter-

restrial and

freshwater

ecosystems

7

14.1 Marine 16

7

12.5 Waste

reduction

15.1 Ter-

restrial and

freshwater

ecosystems

8

5.a Women's 14

economic

8

8.3 Decent job 17

empower-

creation and

growth of

small-sized

enterprises

9

7.2 Renewable 12

energy

9

12.4 Chemi- 16

cal product

management

10

6.1 Access to 9

10

6.1 Access to

water

11

water

11

13.3 Awareness 12

creation and

and capacity

for climate

change

small-sized

enterprises

7.2 Renewable 10

energy

9.5 Science and

technology

13

5.a Women's 7

economic

empower-

ment 


\begin{tabular}{|c|c|c|c|c|c|}
\hline \multicolumn{6}{|c|}{ Second order values } \\
\hline Rank & $\begin{array}{l}\text { Colombia } \\
\text { national } \\
\text { analysis }\end{array}$ & Score & Rank & $\begin{array}{l}\text { Antioquia } \\
\text { analysis }\end{array}$ & Score \\
\hline 1 & $\begin{array}{l}\text { 8.4 Sustainable } \\
\text { consumption } \\
\text { and produc- } \\
\text { tion }\end{array}$ & 425.5 & 1 & $\begin{array}{l}\text { 2.4 Sustainable } \\
\text { agriculture }\end{array}$ & 296 \\
\hline 2 & $\begin{array}{l}\text { 11.6 Envi- } \\
\text { ronmental } \\
\text { impact of } \\
\text { cities }\end{array}$ & 423 & 2 & $\begin{array}{l}\text { 12.5 Waste } \\
\text { reduction }\end{array}$ & 295.5 \\
\hline 3 & $\begin{array}{l}\text { 12.5 Waste } \\
\text { reduction }\end{array}$ & 388.5 & 3 & $\begin{array}{l}\text { 12.4 Chemi- } \\
\text { cal product } \\
\text { management }\end{array}$ & 272 \\
\hline 4 & $\begin{array}{l}\text { 2.4 Sustainable } \\
\text { agriculture }\end{array}$ & 364.5 & 4 & $\begin{array}{l}\text { 11.6 Envi- } \\
\text { ronmental } \\
\text { impact of } \\
\text { cities }\end{array}$ & 257 \\
\hline 5 & $\begin{array}{l}\text { 9.5 Science and } \\
\text { technology }\end{array}$ & 362 & 5 & $\begin{array}{l}\text { 6.3 Water } \\
\text { quality }\end{array}$ & 252 \\
\hline 6 & $\begin{array}{l}\text { 6.4 Water-use } \\
\text { efficiency }\end{array}$ & 348.5 & 6 & $\begin{array}{l}\text { 13.3 Awareness } \\
\text { and capacity } \\
\text { for climate } \\
\text { change }\end{array}$ & 239.5 \\
\hline 7 & $\begin{array}{l}\text { 15.1 Ter- } \\
\text { restrial and } \\
\text { freshwater } \\
\text { ecosystems }\end{array}$ & 314 & 7 & $\begin{array}{l}\text { 9.5 Science and } \\
\text { technology }\end{array}$ & 226.5 \\
\hline 8 & $\begin{array}{l}\text { 12.4 Chemi- } \\
\text { cal product } \\
\text { management }\end{array}$ & 307.5 & 8 & $\begin{array}{l}\text { 15.1 Ter- } \\
\text { restrial and } \\
\text { freshwater } \\
\text { ecosystems }\end{array}$ & 209 \\
\hline 9 & $\begin{array}{l}\text { 13.2 Climate } \\
\text { change and } \\
\text { national poli- } \\
\text { cies }\end{array}$ & 288 & 9 & $\begin{array}{l}\text { 6.6 Water } \\
\text { ecosystems }\end{array}$ & 204.5 \\
\hline 10 & $\begin{array}{l}\text { 8.3 Decent job } \\
\text { creation and } \\
\text { growth of } \\
\text { small-sized } \\
\text { enterprises }\end{array}$ & 235.5 & 10 & 1.5 Resilience & 202.5 \\
\hline 11 & 1.5 Resilience & 231.5 & 11 & $\begin{array}{l}\text { 14.1 Marine } \\
\text { pollution }\end{array}$ & 15 \\
\hline 12 & $\begin{array}{l}\text { 6.1 Access to } \\
\text { water }\end{array}$ & 231 & 12 & $\begin{array}{l}\text { 5.a Women's } \\
\text { economic } \\
\text { empower- } \\
\text { ment }\end{array}$ & 12 \\
\hline 13 & $\begin{array}{l}\text { 1.2 Reduce } \\
\text { poverty }\end{array}$ & 229 & 13 & $\begin{array}{l}\text { 7.2 Renewable } \\
\text { energy }\end{array}$ & 11 \\
\hline 14 & $\begin{array}{c}\text { 6.3 Water } \\
\text { quality }\end{array}$ & 215 & 14 & $\begin{array}{l}\text { 6.1 Access to } \\
\text { water }\end{array}$ & 4 \\
\hline
\end{tabular}




\begin{tabular}{|c|c|c|c|c|c|}
\hline \multicolumn{6}{|c|}{ Second order values } \\
\hline Rank & $\begin{array}{l}\text { Colombia } \\
\text { national } \\
\text { analysis }\end{array}$ & Score & Rank & $\begin{array}{l}\text { Antioquia } \\
\text { analysis }\end{array}$ & Score \\
\hline 15 & $\begin{array}{c}\text { 16.3 Equal } \\
\text { access to } \\
\text { justice }\end{array}$ & 207.5 & 15 & $\begin{array}{c}\text { 8.3 Decent job } \\
\text { creation and } \\
\text { growth of } \\
\text { small-sized } \\
\text { enterprises }\end{array}$ & 0 \\
\hline 16 & $\begin{array}{l}\text { 14.1 Marine } \\
\text { pollution }\end{array}$ & 191.5 & & & \\
\hline 17 & $\begin{array}{l}\text { 2.3 Agriculture } \\
\text { and land }\end{array}$ & 152.5 & & & \\
\hline 18 & $\begin{array}{l}\text { 7.2 Renewable } \\
\text { energy }\end{array}$ & 116.5 & & & \\
\hline 19 & $\begin{array}{l}\text { 5.a Women's } \\
\text { economic } \\
\text { empower- } \\
\text { ment }\end{array}$ & 113.5 & & & \\
\hline 20 & $\begin{array}{l}\text { 3.9 Deaths } \\
\text { from con- } \\
\text { tamination }\end{array}$ & 108.5 & & & \\
\hline
\end{tabular}

Clusters

\begin{tabular}{|c|c|c|c|}
\hline \multicolumn{2}{|l|}{ Colombia } & \multicolumn{2}{|l|}{ Antioquia } \\
\hline Cluster & Targets & Cluster & Targets \\
\hline $\begin{array}{l}\text { 1. Social equity and } \\
\text { poverty reduction }\end{array}$ & $\begin{array}{l}\text { 1.2 Poverty reduction } \\
\text { 2.3 Agriculture and land } \\
\text { 5.a Women's economic } \\
\text { empowerment } \\
\text { 8.3 Decent job creation } \\
\text { and growth of small- } \\
\text { sized enterprises } \\
\text { 16.3 Equal access to } \\
\text { justice }\end{array}$ & 1. Resilience & $\begin{array}{l}\text { 5.a Women's economic } \\
\text { empowerment } \\
\text { 7.2 Renewable energy } \\
\text { 8.3 Decent job creation } \\
\text { and growth of small- } \\
\text { sized } \\
\text { 9.5 Science and technol- } \\
\text { ogy }\end{array}$ \\
\hline $\begin{array}{l}\text { 2. Science, innovation } \\
\text { and technology }\end{array}$ & $\begin{array}{l}\text { 1.5 Resilience } \\
\text { 2.4 Sustainable agri- } \\
\text { culture } \\
\text { 6.4 Water-use efficiency } \\
\text { 7.2 Renewable energy } \\
\text { 9.5 Science and technol- } \\
\text { ogy } \\
\text { 13.2 Climate change and } \\
\text { national policies } \\
\text { 15.1 Terrestrial and } \\
\text { freshwater ecosystems }\end{array}$ & $\begin{array}{l}\text { 2. Sustainable consump- } \\
\text { tion and production }\end{array}$ & $\begin{array}{l}\text { 1.5 Resilience } \\
\text { 6.1 Water access } \\
\text { 13.3 Awareness and } \\
\text { capacity for climate } \\
\text { change }\end{array}$ \\
\hline
\end{tabular}




\begin{tabular}{|c|c|c|c|}
\hline \multicolumn{4}{|l|}{ Clusters } \\
\hline \multicolumn{2}{|l|}{ Colombia } & \multicolumn{2}{|l|}{ Antioquia } \\
\hline Cluster & Targets & Cluster & Targets \\
\hline \multirow[t]{2}{*}{$\begin{array}{l}\text { 3. Waste management } \\
\text { and pollution reduc- } \\
\text { tion }\end{array}$} & $\begin{array}{l}\text { 3.9 Deaths from con- } \\
\text { tamination } \\
\text { 6.1 Water access } \\
\text { 6.3 Water quality } \\
\text { 8.4 Sustainable } \\
\text { consumption and } \\
\text { production } \\
\text { 11.6 Environmental } \\
\text { impact of cities } \\
\text { 12.4 Chemical product } \\
\text { management } \\
\text { 12.5 Waste reduction } \\
\text { 14.1 Marine pollution }\end{array}$ & $\begin{array}{l}\text { 3. Social equity, science, } \\
\text { and innovation }\end{array}$ & $\begin{array}{l}\text { 2.4 Sustainable agriculture } \\
\text { 11.6 Environmental } \\
\text { impact of cities } \\
\text { 12.4 Chemical product } \\
\text { management } \\
\text { 12.5 Waste reduction }\end{array}$ \\
\hline & & 4. Environment & $\begin{array}{l}\text { 6.3 Water quality } \\
\text { 6.6 Water ecosystems } \\
\text { 14.1 Marine pollution } \\
\text { 15.1 Terrestrial and fresh- } \\
\text { water ecosystems }\end{array}$ \\
\hline
\end{tabular}

Acknowledgements We would like to thank all the experts and partners from Colombian national and regional government agencies for their participation in the studies.

Authors' contributions Optional.

Funding Funding for this research was made available from SEI's internal core funds, received from the Swedish International Development Cooperation Agency (SIDA); as well as from a technical cooperation between SEI and the United Nations Environment Programme (UNEP), within the framework of UNEP's project called: "Towards a coherent implementation of the environmental dimension of the SDGs".

Availability of data and material The authors declare that this paper is an accurate and transparent account of the experiments being reported. The full results are available in the content of the manuscript and annexes, and no important data has been omitted. Finally, any discrepancies from the results presented in the manuscript and the full results have been explained.

\section{Declarations}

Conflict of interest The authors have no conflicts of interest to declare that are relevant to the content of this article.

Consent for publication The authors grant the Environment, Development and Sustainability journal the publication rights of this paper, should the editors accept the article. We declare that the manuscript is not under consideration for publication in another journal.

Open Access This article is licensed under a Creative Commons Attribution 4.0 International License, which permits use, sharing, adaptation, distribution and reproduction in any medium or format, as long as you give appropriate credit to the original author(s) and the source, provide a link to the Creative Commons licence, and indicate if changes were made. The images or other third party material in this article are included in the article's Creative Commons licence, unless indicated otherwise in a credit line to the material. If material is not included in the article's Creative Commons licence and your intended use is not permitted by statutory regulation or exceeds the permitted use, you will need to obtain permission directly from the copyright holder. To view a copy of this licence, visit http://creativecommons.org/licenses/by/4.0/. 


\section{References}

Alcamo, J. (2019). Water quality and its interlinkages with the Sustainable Development Goals. Current Opinion in Environmental Sustainability, 36, 126-140. https://doi.org/10.1016/j.cosust.2018.11.005

Allen, C., Metternicht, G., \& Wiedmann, T. (2018). Initial progress in implementing the Sustainable Development Goals (SDGs): A review of evidence from countries. Sustainability Science, 13(5), 1453-1467. https://doi.org/10.1007/s11625-018-0572-3

Allen, C., Metternicht, G., \& Wiedmann, T. (2019). Prioritising SDG targets: Assessing baselines, gaps and interlinkages. Sustainability Science, 14(2), 421-438. https://doi.org/10.1007/s11625-018-0596-8

Bali Swain, R., \& Ranganathan, S. (2021). Modeling interlinkages between sustainable development goals using network analysis. World Development, 138, 105136. https://doi.org/10.1016/j.worlddev.2020. 105136

Banathy, B. H. (1967). The Systems Approach. The Modern Language Journal (Vol. 51). New York: Dell Pub. https://doi.org/10.1111/j.1540-4781.1967.tb02191.x

Barlas, Y. (1996). Formal aspects of model validity and validation in system dynamics. System Dynamics Review, 12(3), 183-210. https://doi.org/10.1002/(sici)1099-1727(199623)12:3\%3c183::aid-sdr103\% 3e3.0.co; $2-4$

Bennich, T., Weitz, N., \& Carlsen, H. (2020). Deciphering the scientific literature on SDG interactions: A review and reading guide. Science of the Total Environment, 728, 1-13. https://doi.org/10.1016/j.scito tenv.2020.138405

Bijl, D. L., Bogaart, P. W., Dekker, S. C., Stehfest, E., de Vries, B. J. M., \& van Vuuren, D. P. (2017). A physically-based model of long-term food demand. Global Environmental Change, 45, 47-62. https:// doi.org/10.1016/j.gloenvcha.2017.04.003

Blondel, V. D., Guillaume, J. L., Lambiotte, R., \& Lefebvre, E. (2008). Fast unfolding of communities in large networks. Journal of Statistical Mechanics: Theory and Experiment. https://doi.org/10.1088/ 1742-5468/2008/10/P10008

Bowen, K. J., Cradock-Henry, N. A., Koch, F., Patterson, J., Häyhä, T., Vogt, J., \& Barbi, F. (2017). Implementing the "Sustainable Development Goals": Towards addressing three key governance challenges-collective action, trade-offs, and accountability. Current Opinion in Environmental Sustainability, 26-27, 90-96. https://doi.org/10.1016/j.cosust.2017.05.002

Breu, T., Bergöö, M., Ebneter, L., Pham-Truffert, M., Bieri, S., Messerli, P., et al. (2020). Where to begin? Defining national strategies for implementing the 2030 Agenda: The case of Switzerland. Sustainability Science, 2030, 1-19. https://doi.org/10.1007/s11625-020-00856-0

Campagnolo, L., Carraro, C., Eboli, F., Farnia, L., Parrado, R., \& Pierfederici, R. (2018). The ex-ante evaluation of achieving Sustainable Development Goals. Social Indicators Research, 136(1), 73-116. https://doi.org/10.1007/s11205-017-1572-X

Checkland, P. B. (1989b). Soft systems methodology. Human Systems Management, 8(4), 273-289. https:// doi.org/10.3233/HSM-1989-8405

Checkland, P. B. (1995). Model validation in soft systems practice. Systems Research, 12(1), 47-54. https:// doi.org/10.1002/sres.3850120108

Checkland, P. B., \& Scholes, J. (1999). Soft systems methodology: A 30-year retrospective. John Wiley.

Checkland, P. B. (1978). The origins and nature of "hard systems" thinking. Journal of Applied Systems Analysis, 5(2), 99-110.

Checkland, P. B. (1989a). Soft Systems Methodology. In H. (Retired) S. Reynolds M. (Ed.), Human Systems Management (Vol. 8, pp. 273-289). London: Springer. https://doi.org/10.3233/HSM-1989-8405

Collste, D., Pedercini, M., \& Cornell, S. E. (2017). Policy coherence to achieve the SDGs: Using integrated simulation models to assess effective policies. Sustainability Science, 12(6), 921-931. https://doi.org/ 10.1007/s11625-017-0457-x

Costanza, R., Daly, L., Fioramonti, L., Giovannini, E., Kubiszewski, I., Mortensen, L. F., et al. (2016). Modelling and measuring sustainable wellbeing in connection with the UN Sustainable Development Goals. Ecological Economics, 130, 350-355. https://doi.org/10.1016/j.ecolecon.2016.07.009

Dörgo, G., Sebestyén, V., \& Abonyi, J. (2018). Evaluating the interconnectedness of the sustainable development goals based on the causality analysis of sustainability indicators. Sustainability (Switzerland), 10(10). https://doi.org/10.3390/su10103766

Fenton, P., \& Gustafsson, S. (2017). Moving from high-level words to local action-governance for urban sustainability in municipalities. Current Opinion in Environmental Sustainability, 26-27, 129-133. https://doi.org/10.1016/j.cosust.2017.07.009

Guerrero, O. A., \& Castañeda, G. (2020). Quantifying the coherence of development policy priorities. Development Policy Review, 1-40,. https://doi.org/10.1111/dpr.12498 
Guijun, L., Yongsheng, W., Daohan, H., \& Hongtao, Y. (2017). A multi-agent model for urban waterenergy-food sustainable development simulation. In ACM International Conference Proceeding Series (Vol. Part F1306, pp. 105-110). https://doi.org/10.1145/3126973.3126991

Hoff, H. (2018). Integrated SDG implementation-how a cross-scale (vertical) and cross-regional nexus approach can complement cross-sectoral (horizontal) integration. In \& R. A. S. Halsmann (Ed.), Managing Water, Soil and Waste Resources to Achieve Sustainable Development Goals: Monitoring and Implementation of Integrated Resources Management (pp. 149-163). Springer. https://doi.org/10.1007/ 978-3-319-75163-4_7

Hutton, C. W., Nicholls, R. J., Lázár, A. N., Chapman, A., Schaafsma, M., \& Salehin, M. (2018). Potential trade-offs between the sustainable development goals in coastal Bangladesh. Sustainability (switzerland), 10(4), 4. https://doi.org/10.3390/su10041108

Inter-Agency and Expert Group on Sustainable Development Goal Indicators. (2016). Report of the InterAgency and Expert Group on Sustainable Development Goal Indicators (E/CN.3/2016/2/Rev.1), Annex IV. Report of the Inter-Agency and Expert Group on Sustainable Development Goal Indicators. United Nations. https://sustainabledevelopment.un.org/content/documents/11803Official-List-of-ProposedSDG-Indicators.pdf

Iyer, G., Calvin, K., Clarke, L., Edmonds, J., Hultman, N., Hartin, C., et al. (2018). Implications of sustainable development considerations for comparability across nationally determined contributions. Nature Climate Change, 8(2), 124-129. https://doi.org/10.1038/s41558-017-0039-z

Jackson, M. C. (1982). Nature of "Soft" Systems Thinking: The Work of Churchman, Ackoff and Checkland. Journal of Applied Systems Analysis, 9, 17-39.

Jackson, M. C. (1985). Social systems theory and practice: The need for a critical approach. International Journal of General Systems, 10(2-3), 135-151. https://doi.org/10.1080/03081078508934877

Jackson, M. C. (2001). Critical systems thinking and practice. European Journal of Operational Research, 128(2), 233-244. https://doi.org/10.1016/S0377-2217(00)00067-9

Järnberg, L., Weitz, N., Maltais, A., \& Carlsen, H. (2021). Interactions among the Sustainable Development Goals in Sri Lanka A systemic assessment. https://doi.org/10.51414/sei2021.004

Jiménez-Aceituno, A., Peterson, G. D., Norström, A. V., Wong, G. Y., \& Downing, A. S. (2020). Local lens for SDG implementation: Lessons from bottom-up approaches in Africa. Sustainability Science, 15(3), 729-743. https://doi.org/10.1007/s11625-019-00746-0

Kanter, D. R., Schwoob, M. H., Baethgen, W. E., Bervejillo, J. E., Carriquiry, M., Dobermann, A., et al. (2016). Translating the Sustainable Development Goals into action: A participatory backcasting approach for developing national agricultural transformation pathways. Global Food Security, 10, 71-79. https://doi.org/10.1016/j.gfs.2016.08.002

Kopainsky, B., Tribaldos, T., \& Ledermann, S. T. (2018). A food systems perspective for food and nutrition security beyond the Post-2015 Development Agenda. Systems Research and Behavioral Science, 35(2), 178-190. https://doi.org/10.1002/sres.2458

Le Blanc, D. (2015). Towards integration at last? The Sustainable Development Goals as a network of targets. Sustainable Development, 23(3), 176-187. https://doi.org/10.1002/sd.1582

Lim, M. M. L., Søgaard Jørgensen, P., \& Wyborn, C. A. (2018). Reframing the sustainable development goals to achieve sustainable development in the anthropocene-a systems approach. Ecology and Society, 23(3). https://doi.org/10.5751/ES-10182-230322

Liu, J. (2017). Integration across a metacoupled world. Ecology and Society, 22(4), 29. https://doi.org/10. 5751/ES-09830-220429

Lusseau, D., \& Mancini, F. (2019). Income-based variation in Sustainable Development Goal interaction networks. Nature Sustainability, 2(3), 242-247. https://doi.org/10.1038/s41893-019-0231-4

Meuleman, L., \& Niestroy, I. (2015). Common but differentiated governance: A metagovernance approach to make the SDGs work. Sustainability (switzerland), 7(9), 12295-12321. https://doi.org/10.3390/ su70912295

Mingers, J. (1984). Subjectivism and soft systems methodology-a critique. Journal of Applied Systems Analysis, 11, 85-103.

Moyer, J. D., \& Bohl, D. K. (2019). Alternative pathways to human development: Assessing trade-offs and synergies in achieving the Sustainable Development Goals. Futures, 105, 199-210. https://doi.org/10. 1016/j.futures.2018.10.007

Nilsson, M., Griggs, D., \& Visbeck, M. (2016). Policy: Map the interactions between Sustainable Development Goals. Nature, 534(7607), 320-322. https://doi.org/10.1038/534320a

Nilsson, M., Chisholm, E., Griggs, D., Howden-Chapman, P., McCollum, D., Messerli, P., et al. (2018). Mapping interactions between the sustainable development goals: Lessons learned and ways forward. Sustainability Science, 13(6), 1489-1503. https://doi.org/10.1007/s11625-018-0604-z 
Nilsson, M., \& Weitz, N. (2019). Governing trade-offs and building coherence in policy-making for the 2030 Agenda. Politics and Governance, 7(4), 254-263. https://doi.org/10.17645/pag.v7i4.2229

Obersteiner, M., Walsh, B., Frank, S., Havlík, P., Cantele, M., \& Liu, J., et al. (2016). Assessing the land resource-food price nexus of the Sustainable Development Goals. Science Advances, 2(9). https://doi. org/10.1126/sciadv.1501499

OECD. (2019). Policy Coherence for Sustainable Development 2019. Policy Coherence for Sustainable Development 2019. Paris: OECD Publishing. https://doi.org/10.1787/a90f851f-en

Oreskes, N. (1998). Evaluation (not validation) of quantitative models. Environmental Health Perspectives, 106(SUPPL. 6), 1453-1460. https://doi.org/10.1289/ehp.98106s61453

Ospina-Forero, L., Castañeda, G., \& Guerrero, O. A. (2020). Estimating networks of sustainable development goals. Information and Management. https://doi.org/10.1016/j.im.2020.103342

Pedercini, M., Zuellich, G., Dianati, K., \& Arquitt, S. (2018). Toward achieving Sustainable Development Goals in Ivory Coast: Simulating pathways to sustainable development. Sustainable Development, 26(6), 588-595. https://doi.org/10.1002/sd.1721

Pfaff, A., Robalino, J., Reis, E. J., Walker, R., Perz, S., Laurance, W., et al. (2018). Roads \& SDGs, tradeoffs and synergies: Learning from Brazil's Amazon in distinguishing frontiers. Economics, 12(2018-11), 1-26. https://doi.org/10.5018/economics-ejournal.ja.2018-11

Pradhan, P., Costa, L., Rybski, D., Lucht, W., \& Kropp, J. P. (2017). A systematic study of Sustainable Development Goal (SDG) interactions. Earth's Future, 5(11), 1169-1179. https://doi.org/10.1002/ 2017EF000632

Reed, J., Vianen, J. Van, \& Sunderland, T. (2015). From global complexity to local reality Aligning implementation pathways for the Sustainable Development Goals and landscape approaches Landscape approach and SDGs : (Vol. 005865). CIFOR. https://doi.org/10.17528/cifor/005864

Rosenthal, J., Quinn, A., Grieshop, A. P., Pillarisetti, A., \& Glass, R. I. (2018). Clean cooking and the SDGs: Integrated analytical approaches to guide energy interventions for health and environment goals. Energy for Sustainable Development, 42, 152-159. https://doi.org/10.1016/j.esd.2017.11.003

Ross, R., \& Hoos, I. R. (1974). Systems Analysis in Public Policy: A Critique. Contemporary Sociology (Vol. 3). Berkeley: University of California Press. https://doi.org/10.2307/2061980

Scherer, L., Behrens, P., de Koning, A., Heijungs, R., Sprecher, B., \& Tukker, A. (2018). Trade-offs between social and environmental Sustainable Development Goals. Environmental Science and Policy, 90, 65-72. https://doi.org/10.1016/j.envsci.2018.10.002

Scott, G., \& Rajabifard, A. (2017). Sustainable development and geospatial information: A strategic framework for integrating a global policy agenda into national geospatial capabilities. Geo-Spatial Information Science, 20(2), 59-76. https://doi.org/10.1080/10095020.2017.1325594

SEI. (2020). SDG Synergies tool. https://www.sdgsynergies.org/

Shelly, M. W. (1965). The New Utopians: A Study of System Design and Social Change, by Robert Boguslaw (Prentice Hall, Englewood Cliffs, N.J., 1965), pp. 213. Naval Research Logistics Quarterly (Vol. 12). Englewood Cliffs: Prentice Hall. https://doi.org/10.1002/nav.3800120311

Sospedra, M., \& Martin, R. (2005). Immunology of multiple sclerosis. Annual Review of Immunology (Vol. 23). Paris: International Council for Science. https://doi.org/10.1146/annurev.immunol.23.021704. 115707

Spaiser, V., Ranganathan, S., Swain, R. B., \& Sumpter, D. J. T. (2017). The sustainable development oxymoron: Quantifying and modelling the incompatibility of sustainable development goals. International Journal of Sustainable Development and World Ecology, 24(6), 457-470. https://doi.org/10.1080/ 13504509.2016.1235624

Stafford-Smith, M., Griggs, D., Gaffney, O., Ullah, F., Reyers, B., Kanie, N., et al. (2017). Integration: The key to implementing the Sustainable Development Goals. Sustainability Science, 12(6), 911-919. https://doi.org/10.1007/s11625-016-0383-3

Stephens, A., Lewis, E. D., \& Reddy, S. (2018). Towards an inclusive systemic evaluation for the SDGs: Gender equality, Environments and Marginalized voices (GEMs). Evaluation, 24(2), 220-236. https:// doi.org/10.1177/1356389018766093

Thomas, A., \& Lockett, M. (1991). Marxism and systems research: Values in practical action. Critical Systems Thinking: Directed Readings. Proceedings of the Silver Anniversary Meeting of the SGSR.

Tyler, G. W. (1979). The future of O.R. Journal of the Operational Research Society, 30(6), 591-594. https://doi.org/10.1057/jors.1979.141

UN. (2016). Transforming our world: The 2030 agenda for sustianable devevlopement. The 2030 Agenda for Sustianability (Vol. 70). https://www.un.org/en/development/desa/population/migration/generalass embly/docs/globalcompact/A_RES_70_1_E.pdf

UN. (2019). The sustainable development goals report 2019. United Nations publication issued by the Department of Economic and Social Affairs. New York: United Nations. https://undocs.org/E/2019/68 
UN. (2020). SDGs Indicator United Nations Global SDG Database. https://unstats.un.org/sdgs/indicators/ database/

Vickers, G. (2018). Policymaking, Communication, and Social Learning : Essays of Sir Geoffrey Vickers. Tavistock Publications Limited.

Voigt, A. (2011). The rise of systems theory in ecology. Ecology Revisited. New York: Wiley. https://doi. org/10.1007/978-90-481-9744-6_15

Wang, Y., Lu, Y., He, G., Wang, C., Yuan, J., \& Cao, X. (2020). Spatial variability of sustainable development goals in China: A provincial level evaluation. Environmental Development, 35.https://doi.org/10. 1016/j.envdev.2019.100483

Weitz, N., Carlsen, H., Nilsson, M., \& Skånberg, K. (2018). Towards systemic and contextual priority setting for implementing the 2030 agenda. Sustainability Science, 13(2), 531-548. https://doi.org/10. 1007/s11625-017-0470-0

Yolles, M. I. (1996). Critical systems thinking, paradigms, and the modelling space. Systems Practice, 9(6), 549-570. https://doi.org/10.1007/BF02169213

Yolles, M. (2020). Towards a general hybrid theory in wicked problem structuring part 1: The foundation. Kybernetes. https://doi.org/10.1108/K-10-2019-0689

Zexian, Y., \& Xuhui, Y. (2010). A revolution in the field of systems thinking-a review of Checkland's system thinking. Systems Research and Behavioral Science, 27(2), 140-155. https://doi.org/10.1002/sres. 1021

Zhou, X., \& Moinuddin, M. (2017). Sustainable Development Goals Interlinkages and Network Analysis: A practical tool for SDG integration and policy coherence. The Institute for Global Environmental Strategies (IGES). Hayama: Institute for Global Environmental Strategies. https://sdginterlinkages.iges.jp/ files/IGES_Research\%20Report_SDG\%20Interlinkages_Publication.pdf

Publisher's Note Springer Nature remains neutral with regard to jurisdictional claims in published maps and institutional affiliations. 